\title{
Mekânsal Planların Çevresel Sürdürülebilirlik Performansının Belirlenmesine Yönelik CBS Aracı Geliştirilmesi
}

\section{Development of a GIS Tool for the Identification of Environmental Sustainability Performance of Spatial Plans}

\author{
(D) Emin Yahya Menteşe, ${ }^{1}$ (1) Azime Tezer, ${ }^{1}$ (1) Mehmet Demir ${ }^{2}$
}

${ }^{1}$ Istanbul Teknik Üniversitesi, Şehir ve Bölge Planlama Bölümü, İstanbul

${ }^{2}$ RKSoft Mühendislik Bilgisayar Programlama Ltd.Şti.

\section{ÖZ}

Mekânsal gelişimin temel bileşeni olan planların; uygulandıkları alan üzerinde yaratacağı etki planlama sürecinin öncelikli konularından biridir. Bu nedenle planlama sürecinde söz konusu etkinin analiz edilmesi ve anlaşılması önemli bir aşamayı oluşturmaktadır. Bu çalışma, planlama sürecine bir katkı sunma ve bu süreci iyileştirme amacıyla; planların uygulanacakları mekânın çevresel sürdürülebilirlik potansiyeline olan etkisini analitik biçimde modelleyebilmeyi hedeflemektedir. Böylece planın doğal kaynakların kullanımına, tüketimine ve sürdürülebilmesine nasıl katkı/etki sağladığı ölçülerek; henüz hazırlık aşamasında bu bakış açısıyla değerlendirilmesi sağlanabilmektedir. Günümüzde mekânsal planların sebep olabileceği çevresel sonuçlar, mevcut doğal çevrenin boyutu, büyüklüğü veya kapladığı alanı ne kadar artıracağı veya azaltacağı, kişi başına düşen yeşil alan miktarını ne oranda değiştirdiği gibi bileşenler üzerinden değerlendirilmektedir. Buna karşın bir planın mevcut ekosistem işleyişine olası somut etkisi analitik bir yöntemle ele alınmamaktadır. Örneğin bir planın hava kalitesinin nasıl değişeceği; su kaynaklarının gelecekteki yeterliği ve kullanımı; biyolojik çeşitliliğin ne oranda devam edeceği tam olarak analiz edilmemekte veya edilememektedir. Bu yaklaşım planların uygulandıkları mekân üzerinde öngörülemeyen etkiler yaratmasına ve bu alanların yaşanamaz bir hale dönüşmesine neden olabilmektedir. Planlama sürecindeki bu eksikliği gidermeye yönelik olarak, bu araştırma ile geliştirilen model; çevresel sürdürülebilirliğin ekosistem servisleri temel alınarak tanımlanması ve özellikle üst ölçek stratejik mekânsal planlarla önerilen fonksiyonların ekosistemler tarafından sağlanan servisleri ve faydaları ne şekilde etkilediğinin ortaya koyulmasını içermektedir.

\section{ABSTRACT}

Impacts caused by plans that are the primary components of spatial development are one of the initial subjects of the planning process. Therefore, analysing and understanding the impacts of the plans constitute a critical stage in this process. With the aim of contributing and enhancing planning procedures, this study focuses on modelling the impacts of plans on environmental sustainability state of the planning area with an analytical approach. Thereby a plan can be assessed based on its impact/benefit on the use, consumption and sustaining of the natural resources. Today, possible environmental results of the plans are estimated mostly based on changes in quantity values such as changes of size or area of natural environments or changes of green space area per person. On the other hand, a plan's tangible results on the ecosystem process are not analyzed via an analytical method. For example, a plan's impact on air quality, adequacy of water resources or continuity of biodiversity is not or cannot be assessed. This sort of implementation leads to unexpected effects occurred by plans and transforms cities into unlivable areas. To remove this gap in planning process; this research focuses on development of a model that enables to define environmental sustainability as a function of ecosystem services and evaluate the impacts of especially strategic level spatial plans on services and benefits provided by ecosystems. In recent studies, there are various methods developed for understanding the ecosystem service potential of land uses. Among these models, Burkhard et al.s (2009) study is notable by implementing an efficient matrix model that includes ecosystem service potentials of land uses. The values of the potential are gathered by the expert-based and data-based scoring of each land use's ecosystem services potential. 
Gerçekleştirilen araştırmalarda mekânsal kullanımın ekosistem servisleri sağlama potansiyelinin anlaşılmasına yönelik etkin yöntemler geliştirildiği tespit edilmiştir. Bu yöntemler arasında Burkhard ve diğ. (2009) tarafından geliştirilen matris modeli önemli bir yere sahiptir. Söz konusu çalışma ile arazi kullanım türlerinin ekosistem servisi sağlama potansiyelleri uzman görüşleri ve ölçüme dayalı veriler temel alınarak puanlandırımaktadır. Bu araştırmada söz konusu matris modeli yeniden ele alınarak mekânsal kullanımın yalnızca sağladığı faydaları değil neden olduğu etkileri de kapsayacak şekilde genişletilmiştir. Sonrasında mekânsal kullanımın hem sağladığı fayda hem de neden olabileceği zarar Coğrafi Bilgi Sistemleri (CBS) tabanlı bir yazılım geliştirilerek değerlendirilmiş ve mekânsal plan ile planın uygulanacağı arazinin çevresel sürdürülebilirlik performansının analiz edilmesi sağlanmıştır. Bu sayede mekânsal planların çevresel sürdürülebilirlik ile ilişkisi modellenmiştir.

Anahtar sözcükler: Coğrafi bilgi sistemleri; çevresel sürdürülebilirlik; mekânsal planlama; ekosistem servisleri; etki analizi.

\section{Giriş}

Dünya genelindeki en benimsenmiş ve kabul görmüş sürdürülebilirlik tanımlarından biri 1987 yılında düzenlenen Birleşmiş Milletler Çevresel Kalkınma Konferansı sonucunda yayınlanan Brundtland Raporu'nda yer alan sürdürülebilirlik tanımıdır. Raporda sürdürülebilir kalkınma, gelecek nesilleri kendilerini geliştirme/kalkındırma imkânlarından taviz vermek zorunda bırakmadan günümüzde kalkınmayı sağlayacak yaklaşım olarak ifade edilmiştir. (BM, 1987). Bu çerçevede doğal kaynak tüketimine neden olan insan aktivitelerinin sınırlı bir seviyede tutularak gelecekte bu kaynakların aynı şekilde kullanabilmesinin sağlanması uzmanlarca üzerinde fikir birliği sağlanan bir konudur (Arrow vd, 1995). Bunun için, kalkınmanın temel yapıtaşlarından biri olan kentleşmenin etkin yöntemler kullanılarak yönetilmesi ve yönlendirilmesi gerekmektedir. Bu süreçte kentlerin planlı bir şekilde gelişmeleri, toplumların geçmişteki yanlış uygulamalar sonucunda ortaya çıkan çevre sorunlarıyla mücadele etmelerinde en önemli ihtiyaçlardan biridir (BMHabitat, 2002), (Vega-Azamar vd, 20I5).

Kentlerin planlı gelişimini destekleyecek en önemli uygulama araçlarından biri sürdürülebilir mekânsal planlamadır. 1992 tarihli Rio Konferansı sonuç bildirgesinde (Gündem 2I) açık olarak tanımlanan ve küresel ölçekte yer bulan sürdürülebilir mekânsal planlama kavramı, toplumların sürdürülebilir kalkınmasında temel öncelik alanlarından biri olarak rol oynamaktadır (BM, 1992). Bildirgede çevresel, sosyal ve ekonomik olarak sürdürülebilirliği sağlamanın temel önceliklerinden birinin de sürdürülebilir mekânsal planlama olduğu vurgulanmıştır (BM, 1992). Leitao ve Ahern (2002) tarafından mekânsal planlama, peyzaj ekolojisi, çevresel etki değerlendirme ve ekosistem yönetimi üzerine yapılan detaylı literatür değerlendirmesinde; sürdürülebilir mekânsal planlamanın, planlama disiplininin 21 . yüzyıldaki evriminin kaçınılmaz sonucu olduğu ve sürdürülebilirlik kavramının temel bileşenlerinin planlama süreci içinde daha etkin bir şekilde yer alması gerektiği vurgulanmaktadır.
In this research matrix model is re-evaluated and expanded to include the impacts of land uses in addition to ecosystem services. Hence both the benefits and harms on ecosystems occurred by land use are involved in the matrix. Then these values are integrated into GIS; consequences of a plan on current land are and sustainability performance of the plan and implementation area is analyzed. As a result, relationship between environmental sustainability and land use plan is modelled.

Keywords: Ecosystem services; environmental sustainability; land use planning; geographic information systems; impact analysis.

Ancak diğer taraftan, planlama disiplininin ekolojik planlamanın gerektirdiği prensiplere yeterince adapte olamadığı ve bu nedenle de sürdürülebilir mekânsal planlamanın çok daha etkin bir şekilde bu sürece dâhil edilmesi gerektiği belirtilmekte ve bunu kolaylaştıracak uygulama ve/veya analiz araçlarına ihtiyaç duyulmakta olduğu bildirilmektedir (Leitao and Ahern, 2002). Özellikle ekolojik sistemin fragmantasyon gibi mekânsal süreçlerle olan ilişkisi daha derinlemesine çözümlenebilmekle birlikte (van Lier, 1998); bu ilişkinin mekânsal karar destek süreçlerine entegre edilmesi ve ekosistemlerin mekânsal kullanımla olan çok boyutlu ilişkisinin anlaşılabilmesi için analiz ve uygulama araçlarına olan gereksinim gün geçtikçe artmaktadır. Buna ek olarak mekânın kullanımı tasarlanırken, doğal çevrenin sıklıkla durağan bir varlık olarak ele alınması, doğal yapının sağlamakta olduğu faydaların göz ardı edilmesine neden olmaktadır. Ancak günümüzde mekânsal kullanımın fiziki çevre üzerindeki etkisinin anlaşılmasına yönelik birtakım analiz yöntemleri geliştirilmiş olmasına rağmen, geniş çevrelerce kabul görmüş bir yaklaşım bulunmamakta ve söz konusu analiz yöntemleri, mekânsal kullanım tercihlerinin neden olduğu etkiler ve yarattığı sonuçlar üzerine değil; mevcut mekânsal kullanımda neden olunan değişiklikler üzerine olduğu aktarılmaktadır (Hersperger, 2017). Bu çerçevede başta uygulayıcılar ve karar vericiler olmak üzere tüm planlama paydaşlarının; geçmiş uygulamalardan ders almak ve mekânsal kullanım kalitesini artırabilmek için planlama sürecinin ekosistemler üzerindeki sonuçlarını ve etkilerini değerlendirebilmesi önem taşımaktadır (Seasons, 2003).

Sürdürülebilirlik kavramının analizine yönelik yapılan çalışmalara bakıldığında sürdürülebilirliğin ölçülebilir hale getirilmesi, geçerli göstergelerin belirlenmesi ve bu göstergelere dayaIı endekslerin oluşturulması ile mümkündür (Alberti, 1996, Mori ve Christodoulou, 20I2, Singh vd, 20I2). Literatürde yer alan sürdürülebilirlik endeksleri, içerikleri itibariyle farklılaşmalarına rağmen; hava kalitesi, su kalitesi, toprak kalitesi ve ekosistem çeşitliliği konuları sürdürülebilirliğin çevresel bile- 
şeninin ifade edilmesinde ortak payda olarak kullanılmaktadır. Bu kavramların mekânsal plan ile ilişkisinin kurulmasındaysa detaylı ölçüm veya veri kayıtlarına ihtiyaç duyulmaktadır. Örneğin kentsel kullanımın hava kalitesine etkisinin anlaşılabilmesi için o bölgede hava kalitesi ölçüm verilerine ihtiyaç duyulduğu gibi kentsel kullanımın niteliği ve içeriğine dair bilgilere de ihtiyaç duyulmaktadır. Ancak ihtiyaç duyulan verilerin çoğu zaman analize altlık olabilecek içerik ve detayda var olmaması nedeniyle bu araştırmada mekânsal kullanım ve sürdürülebilirlik ilişkisinin ortaya konulmasında mekânsal kullanımın ekosistem servisleri (ES) potansiyeli esas alınmıştır. Özellikle ES ve mekânsal kullanım ilişkisinin kurulmasında uygulama alanına ait ölçüme dayalı verilerin bulunmaması durumunda uzman görüşlerine dayalı ilişkilendirmenin verimli sonuçlar verdiği bilinmektedir (Burkhard vd, 2009; Jacobs ve Burkhard, 2017; Campagne ve Roche; 2018). Buna ek olarak ES'nin gerek doğa-insan etkileşimini mekân boyutuyla inceleyen bir araç olması; gerekse de mekânın kullanım biçiminin neden olacağı etki veya sağlayacağı faydayı yorumlamaya imkân tanıması ES yaklaşımının tercih edilmesinde önemli bir sebeptir. Dolayısıyla ES kavramı çevresel kalite ve mekânsal kullanım ilişkisinin tanımlanmasında önemli bir bileşen olarak ortaya çıkmaktadır (Burkhard vd, 2009, 2014, Jacobs vd, 2015).

Bu araştırmada çevresel sürdürülebilirlik kavramı ve mekânsal plan ilişkisi Burkhard vd, (2009) tarafından geliştirilen ve arazi örtüsünün sağladığı ES potansiyelinin etkin bir şekilde değerlendirilmesini sağlayan matris yaklaşımından yola çıkılarak kurgulanmaktadır. Matris yaklaşımında her bir arazi örtüsünün sahip olduğu ES potansiyeli uzman görüşü ve sayısal ölçüm verileri temel alınarak 0 ile 5 arasında puanlanmaktadır. Bir alansal kullanım türünün ES potansiyelinin alabileceği en düşük puan 0 (sıfır) iken, en yüksek değer 5'tir. Matris yaklaşımı literatürde yer alan birçok farklı çalışmada (Hermann vd, 2013; Kroll vd, 20I2; Stoll vd, 20I5; Vihervaara vd, 2010; Cai vd, 2017; Cottillon, 20I3; Kaiser vd, 2013, Campagne vd, 2017; Paudyal vd, 20I5; Nedkov ve Burkhard, 20I2; Depellegrin vd, 2016) mekân kullanım türleri ve ES potansiyeli arasındaki ilişkinin incelenmesi ve çalışma alanlarındaki mekânsal kullanım türlerinin üretebileceği toplam ES potansiyelinin ölçülmesinde kullanılmıştır (Campagne ve Roche, 2018). Ancak bu uygulamalarda temel hedef ES potansiyelinin belirlenmesi olduğu için; bir mekânsal kullanım türünün yalnızca fayda sağlayan tarafı ele alınmakta, kullanımlardan doğan olumsuz sonuçlar değerlendirme dışında bırakılmaktadır. Halbuki mekânsal kullanımlar ekolojik açıdan faydalar sağlayabilmekle birlikte, olumsuz etkilere de neden olmaktadır. Sürdürülebilir mekan kullanımı içinse mekânsal kullanımın neden olduğu etkilerin o bölgedeki ekolojik limitleri aşmaması gerekmektedir (White ve Whitney, 1992). Bir başka ifadeyle belli bir bölgedeki mekânsal kullanım, hem olumlu hem de olumsuz etki yaratmakta fakat sürdürülebilir bir çevre için olumlu etkilerin olumsuz etkilerden fazla olması beklenmektedir.
$\mathrm{Bu}$ nedenle bu araştırmada matris yaklaşımında güncelleme yapılarak çevresel sürdürülebilirlik düzeyinin ölçülmesinde mekânsal kullanımdan kaynaklanan olumsuz etkiler de dikkate alınmıştır. Bunun için bir mekânsal kullanım türünün sebep olabileceği olumsuz çevresel etkiler, negatif değerler alarak matrise dâhil edilmiştir. Buna ek olarak mekânsal kullanım türlerinin alansal büyüklüklerinin, çevresel sürdürülebilirlik düzeyinde yaratılan etkiler ve/veya katkılar ile doğru orantılı olacağı varsayılmıştır. Bu nedenle bir mekânsal kullanım türünün alanı büyüdükçe ES potansiyeli veya ilgili ekosistemde yarattığı olumsuz etkisinin artacağı kabul edilmektedir. Bu nedenle çaıısma kapsamındaki matris yaklaşımına, olumsuz etkilerin yanı sıra alansal büyüklük bileşeni de katılmıştır.

Benimsenen yaklaşımda, mekânsal kullanımın çevresel sürdürülebilirlik düzeyi, mekânsal plan temel alınarak hesaplanmaktadır. Mekânsal planın uygulama alanındaki çevresel sürdürülebilirliğe olan etkisinin değerlendirilmesinde ise uygulama alanının ekolojik kalitesini daha ileriye taşıması veya en azından o bölgedeki durumu daha kötüye götürmemesi beklenmektedir. Bu sebeple geliştirilen yöntemde öneri planın çevresel sürdürülebilirlik düzeyi uygulama alanının mevcut durumu ile ayrıca karşılaştırılmakta ve planın ekosisteme ne şekilde etki ettiği veya katkı sağladığı değerlendirilmektedir. Bu yöntem adımlarının gerçekleştirilmesi için Coğrafi Bilgi Sistemi (CBS) tabanlı bir yazılım olan "Environmental Sustainability Assessment Tool” (EnSAT) geliştirilmiştir. EnSAT ile uygulama alanın mevcut durumdaki çevresel sürdürülebilirlik düzeyi ile mekânsal planın çevresel sürdürülebilirlik düzeyi hesaplanabilmekte; plan durumu ve mevcut durum sürdürülebilirlik düzeyleri karşılaştırılabilmektedir. Böylelikle başta plancılar olmak üzere ilgili tüm karar vericilerin faydalanabileceği ve planların daha sürdürülebilir yaşam alanları yaratılmasında sağlayabileceği katkılar analiz edilebilmektedir.

Geliştirilen yöntemin ES tabanlı göstergelere dayalı olması itibariyle üst ölçek planlarda entegre edilmesinin daha anlamIı sonuçlar üreteceği öngörülmüştür. Geliştirilen yöntem ve yazılımın rasyonel sonuçlar ürettiğini ispatlamak üzere tutarlıIık ve geçerlilik testleri yapılmış; yöntem adımları İstanbul ölçeğinde seçilen bir örnek alanda uygulanmıştır. Ayrıca tercih edilen ES bileşenlerinin çevresel sürdürülebilirliği temsil etme kapasitesi; BM Sürdürülebilir Kalkınma Göstergelerine (20I7) dayalı bir endeksle karşılaştırma yapılarak test edilmiş ve yöntemin tutarlı sonuçlar ürettiği tespit edilmiştir.

\section{Sürdürülebilir Mekânsal Planlama ve Ekosistem Servisleri}

2007'den itibaren dünya üzerindeki nüfusun yarısından fazlası kentlerde yaşamakta olduğu bilinmekte ve 2030 itibariyle kentli nüfusun 5 milyara yükseleceği öngörülmektedir (BM, 20II). Buna bağlı olarak şehirler büyümekte ve şehirli nüfus 
arttıkça şehirlerin kaynak ihtiyacı mekânsal planlamanın en temel konularından biri haline gelmektedir (Vega-Azamar vd, 20I5). Kentleşmenin ve buna bağlı kaynak ihtiyacının artması ile ilgili küresel ölçekteki en kritik uyarı, ilk olarak Birleşmiş Milletler "Gündem 2l" bildirisi ile yapılmıştır (BM, 1992). Gündem 2I bildirisinde kaynaklara erişim, sürdürülebilir yaşam tarzının en temel bileşeni olarak ele alınmakta olup; bu kaynakların başta insanlar olmak üzere tüm yaşayan sistemlerin temeli olduğu ve tüm insan faaliyetlerine olanak sağladığı vurgulanmaktadır. Kentsel büyümenin sonucu olarak da, kentlerde ihtiyaç duyulan sanayi, konut, ticaret ve tarımsal alan talepleri açık alanlar ile karşılanmakta ve dolayısıyla özellikle ekolojik açıdan hassas açı/kırsal arazilerin ticari çıkarlar ön planda tutularak farklı arazi kullanımlarına dönüştürülmesi gibi sürdürülebilir olmayan uygulamalar ile çevresel bozulma gitgide hızlanmaktadır (BM, 1992).

BM Sürdürülebilir Kalkınma Hedefleri 2017 Gelişme Raporu'na göre dünya nüfusunun kentlere yönelmesiyle kentlerin coğrafi sınırları genişlemektedir. 2000'den 2015'e gelindiğinde kentlerdeki alansal büyüme oranı nüfusun büyüme oranını üzerine çıkarak; kentsel saçaklanma ve plansız büyüme dinamikleri sürdürülebilir olmayan şekilde kent çeperlerinde ve kırsal alanlarda yeni gelişme odakları oluşarak yapılaşmamış alanları hızla tüketmiştir (BM, 20I7). Kentlerin bu gelişim sürecindeki boyutları ve mekânsal kullanım biçimleri ekolojik dengeyi etkileyen temel unsurlar olarak ön plana çıkmaktadır (Orishimo, 1982). Kentlerin saçaklanarak genişlemesi ulaşım mesafelerinde artışlar, trafik ve hava kirliliği problemleri ile ekolojik hassasiyeti olan alanların parçalanması gibi birçok olumsuz sonucu ortaya çıkarmakta ve dolayısıyla ekosistemlerin fayda sağlama kapasitesi azalarak özellikle kentsel alanlarda çevresel kaliteyi düşürmektedir (Kışlalıoğlu ve Berkes, 2007). Bu sebeple, çevresel kalitenin ve doğal kaynakların sürdürülebilirliği için mekansal kullanım fonksiyonlarının belirlenmesinde; bir diğer ifadeyle mekânın planlanmasında çevresel kaygıların dikkate alınması büyük önem taşımaktadır (Chen vd, 20I5).

Sürdürülebilir kentlerin gelişmesinde kentsel sistemin daha bütüncül bir şekilde anlaşılması ve kent fonksiyonları ile kent ekolojisi arasındaki ilişkinin net bir şekilde ortaya konulması gerekmektedir (Pauleit ve Duhme, 2000). Nitekim “kentsel gelişmenin mekânsal sınırlarını ekolojik kaynak ve değerleri esas alarak tanımlayan, çevre-ekoloji öncelikli planlama yaklaşımı"nın sürdürülebilir mekânsal planlamanın temel bileşenlerinden biri olduğu literatürde sıklıkla vurgulanmaktadır (Geenhuisan ve Nijkamp, 1994; Fawcett-Thompson, 1996; Diepen ve Voogd, 200 I; Alshuwaikhat ve Nkwenti, 2002; Özcan, 2016).

Ancak halen mekânsal tasarım veya mekânsal kullanım biçimlerinin çevresel sürdürülebilirliğe olan etkisi üzerine geliştirilen yöntemlerde fikir birliği sağlanabilmiş değildir. Buna ek olarak arazi kullanımındaki değişikliklerin çevresel etkilerinin analitik olarak ele alınmadığı ve sayısal analiz yöntemlerinin bulunmadığı da bilinmektedir (Petit vd, 200I). Mekânsal planlama süreçlerinde genel işleyiş planlanacak alanla ilgili çevresel, yer-bilimsel, sosyo-ekonomik vb. temel verilerin toplanması, analiz edilmesi ve plan hedef ve vizyonu doğrultusunda sentezlenerek mekânsal kullanım türlerinin atanması şeklinde gerçekleşmektedir. Ancak bu süreçlerde ekosistemler yaşayan birer organizma gibi değil, yalnızca birer arazi örtüsü şeklinde değerlendirilmektedir. Bu durum ekosistemlerin gerçek öneminin ve faydalarının göz ardı edilerek ekolojik limitlerin çoğunlukla aşılmasına ve kaynakların aşırı tüketimine neden olmaktadır. Bu noktada ekosistemlerin sağladığı servis ve faydaların optimum seviyede kalması çevresel sürdürülebilirliğin en temel bileşenidir (Milennium Ecosystem Assessment (MEA), 2003) ve mekânsal kullanımlarda yaşanan değişimlerin ES’ler üzerindeki etkisi çevresel sürdürülebilirliği de etkilemektedir (Costanza vd, 1997). Bu durum kent ölçeğinde ele alındığında kentsel gelişimin ekosistemler üzerinde olumsuz etkiler yaratması yanı sıra (Colding, 20II); kentlerin sahip olduğu doğal veya yarı doğal ekosistemler sayesinde ekolojik açıdan birçok fayda sağladığı da bilinmektedir. Bu faydalar ile olumsuz etkilerin bütünleşik olarak değerlendirilmesiyle mekânsal gelişimin sürdürülebilirliği analiz edilebilmektedir (Wiggering vd, 2003).

Bu kapsamda mekânsal planlama faaliyetlerinin ekosistemlerin işlevleri, faydaları ve sundukları ürünleri (yani ES’leri) dikkate alarak yürütülmesi çevre koruma ve sürdürülebilir kalkınma açısından daha rasyonel sonuçlar ortaya koymaktadır (Groot, 2006). Bu doğrultuda kentleşme kaynaklı arazi kullanım değişikliğine bağlı olarak ES’lerin sürdürülebilirliğine yönelik yönetim ve alan kullanım politikalarının geliştirilmesi gerekmektedir (Söderman vd, 20I2). Bu temelden hareketle, mekânsal planlama ile olası ekolojik bozulmanın kontrol altında tutulabilmesi ve mekânın akılcı ve sağlıklı bir biçimde kullanılabilmesi için; giderek kısıtlı hale gelen kaynakların ES’lerin sürdürülebilirliğine odaklanarak yönetilmesi ve mekânsal planlama süreciyle ile bütünleştirilmesi gerekmektedir (Perminova vd, 20l6).

Sürdürülebilirlik kavramı çerçevesinde; kentsel gelişimin çevresel açıdan sürdürülebilirliği temel olarak uygulama bölgesindeki ekolojik taşıma kapasitesini aşmamasıyla ilişkilidir. Bu sebeple planlamanın çevresel sürdürülebilirlik değerlendirmesi yapılırken mekânsal planların ekolojik taşıma kapasitesine veya ES potansiyeline ne şekilde etki edeceğinin, yani planın uygulama alanı üzerindeki ekolojik durumu ne şekilde değiştireceğinin öngörülmesi; akılcı plan kararlarının üretilmesi için önem kazanmaktadır. Bu noktada ES yaklaşımı, mekânsal kullanımın sağladığı ekolojik faydaları ortaya koyarak; mekânsal planların ekolojiyle olan karşılıklı etkileşimini çevresel sürdürülebilirlik açısından değerlendirilmesinde kullanılabilmektedir (Sumarga ve Hein, 2015). 


\section{Yöntem}

Mekânsal kullanım kararlarının alınması ve plan yapım süreçlerinde, teknik olarak çeşitli parametrelerin kullanımasının yanı sıra hukuki, sosyo-ekonomik ve yönetsel bileşenler yer almaktadır. Dolayısıyla planlama sürecinde yalnızca teknik değil, sosyal ve idari değişkenler de rol oynamaktadır. Örneğin, mekânsal planlama sürecinde mekâna dair verilerin temini, değerlendirilmesi, sentezlenmesi gibi teknik bir yaklaşım uygulanırken; planların sürdürülebilir olması için ilgili paydaşların katılımcılığının sağlanması, paydaşlar arasındaki yetki ve sorumluluk seviyelerinin belirgin olması, toplumun sürece katılımının sağlanması gibi nitel ölçütler de tanımlanmaktadır (BM-HABITAT, 2002). $\mathrm{Bu}$ sebeple tüm bu sürecin sürdürülebilirlik açısından performansının analitik bir yaklaşımla analiz edilmesi tam olarak mümkün gözükmemektedir. Buna karşın mekânsal planların hâlihazırda tüm planlama sürecinin somut ve sonuç çıktısı olması ve planlama sürecinin bir sentezi olarak mekânsal kullanıma yön veren en temel bileşen olması sebebiyle bu araştırmada planlama sürecinin nitel bileşenleri değil yalnızca nihai ürünü olan mekânsal planların çevresel sürdürülebilirlik düzeyi değerlendirilmektedir. Bu yaklaşımın özellikle stratejik mekânsal planlamanın performans analizi için etkin bir yöntem teşkil edeceği öngörülmektedir.

Geliştirilen yöntemin temelinde kentsel gelişimi yönlendiren mekânsal planların yalnızca kentsel kullanımlara yönelik fonksiyonlar değil, doğal kaynakların korunmasına ilişkin bileşenleri de içerdiği ve böylece ekolojik fayda yaratacağı da kabul edilmektedir. Benzer yaklaşım bir Avrupa Birliği araştırma projesi olan "Sustainability Impact Assessment Tools for Environmental, Social and Economic Effects of Multifunctional Land Use in European Regions-SENSOR" kapsamında da geliştirilmiş ve mekânsal kullanım türlerindeki (kentsel, sanayi, tarım vs.) değişikliklerin sürdürülebilirliğe olan etkisi olumlu ve olumsuz yönleriyle analiz edilmiştir (Helming vd, 2008). Benzer şekilde, bu araştırmada da mekânsal planın çevresel sürdürülebilirlik düzeyi özgün bir yaklaşımla değerlendirilerek; mekânsal planın içerik olarak ES'ler üzerindeki olumsuz etkisi ile olumlu katkıları arasındaki farkı ortaya koyarak nihai ürünün performansının hesaplanmasına dayanmaktadır (Şekil I). Bir başka ifadeyle "bir alana dair mekânsal plan veya mekânsal kullanımın çevresel açıdan sürdürülebilir

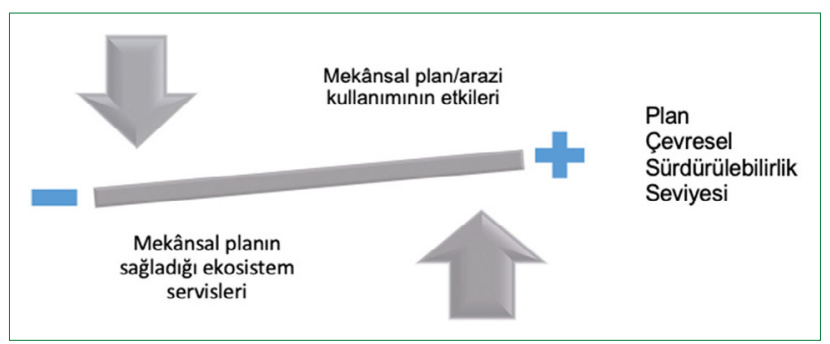

Şekil I. Yöntem temel yaklaşımı olması için ürettiği ekolojik faydanın neden olduğu ekolojik zarardan fazla olması gerektiği" kabulü ile değerlendirme yapılmaktadır. Bu yaklaşım; sürdürülebilirlik kavramı için White ve Whitney (1992) tarafından geliştirilen "mekânsal kullanımın çevresel açıdan neden olduğu etkilerin söz konusu bölgedeki ekolojik limitleri aşmaması" tanımı ile de örtüşmekte ve çevresel sürdürülebilirlik değerlendirmesini analitik bir temele oturtmaktadır.

Araştırma yaklaşımının ölçülebilir ve karşılaştırılabilir bir içeriğe dönüştürülebilmesi için ise, Burkhard vd. $(2009,2014)$ tarafından geliştirilen ve arazi örtüsünün sağladığı ES potansiyelinin değerlendirilmesi ve haritalanması amacıyla geliştirilmiş olan "matris yaklaşımı" temel alınmıştır. Matris yaklaşımında, arazi kullanımı/arazi örtüsünün sağladığı ES potansiyeli o kullanım ile ilişkili çevresel parametrelerin (hava kalitesi, su kalitesi, toprak kalitesi vb.) ölçüm verileri ve/veya söz konusu mekânsal kullanımın ES potansiyeline ilişkin uzman görüşleri kullanılarak değerlendirilmektedir. Bu araştırmada ise matris yaklaşımına ek olarak; ES bileşenlerinin çevresel sürdürülebilirlik kavramını tam anlamıyla karşılayabilmesi için mekânsal kullanım türlerinin negatif etkileri de analize katılmışır. Böylelikle mekânsal kullanım türüne bağlı olarak alanda üretilen ES ile alandaki ekosistemlerin maruz kaldığı baskılar bütünleşik bir şekilde temsil edilebilmekte; mekânsal kullanımın hem ES sağlama potansiyeli, hem de ekolojik zarar yaratma potansiyeli çevresel sürdürülebilirlik kavramını tanımlayacak şekilde ele alınmaktadır. Ayrıca mekânsal kullanım türünün alansal büyüklüğü hem sağlanan fayda hem de neden olunan etki ile doğru orantılı olacağından, alansal büyüklük bileşeni ölçümlere ve karşılaştırmalara dâhil edilmiştir. Böylelikle mekânsal kullanım kararlarının nitelik ve nicelik açısından değerlendirilmesi gerçekleştirilebilmiştir.

Yöntem adımlarında öncelikli olarak mekânsal planların çevresel sürdürülebilirlik düzeyinin değerlendirilebilmesi için hangi bileşenlerin temel alınacağı tespit edilmiştir. Uluslararası düzeyde kabul görmüş çeşitli endeksler incelendiğinde, su kalitesi/varlığı, hava kalitesi, toprak kalitesi ve biyoçeşitlilik parametrelerinin ortaklaşan noktalar olduğu görülmektedir. (Singh vd, 2012, Tablo I).

Yöntemin ikinci safhasında ise çevresel sürdürülebilirlik bileşenlerinin hangi ES parametreleri ile eşleştirileceği belirlenmiştir. Buna yönelik olarak ES literatürü incelendiğinde üç ana ES sınıflandırmasının Millennium Ecosystem Assessment (MEA) (2003), The Economics of Ecosystems and Biodiversity (TEEB) (2008), Common International Classification of Ecosystem Services (CICES) (Haines-Young ve Potschin, 2013) var olduğu görülmektedir. Bu çalışmada sistematik olarak revize edilmesi ve diğer çalışmalardan daha güncel olması nedeniyle CICES kapsamında belirtilen ES türleri temel alınmış ve adapte edilmiştir. 
Tablo I. Çevresel sürdürülebilirlik temel bileşenleri

\begin{tabular}{|c|c|c|c|c|c|c|c|c|}
\hline \multirow[t]{2}{*}{ Endeks adı } & \multirow[t]{2}{*}{ İlgili kurum-kuruluş } & \multicolumn{7}{|c|}{ Değerlendirilen gösterge başlıkları } \\
\hline & & $\begin{array}{c}\text { Hava } \\
\text { Kalitesi }\end{array}$ & Su kalitesi & $\begin{array}{l}\text { Toprak } \\
\text { kalitesi }\end{array}$ & Biyoçeşitlilik & Enerji & İklim & Atık \\
\hline $\begin{array}{l}\text { Millennium Development } \\
\text { Goals (2000) }\end{array}$ & Birleşmiş Milletler & $x$ & $x$ & $x$ & $x$ & - & - & - \\
\hline $\begin{array}{l}\text { Sustainable City Index } \\
(2014)\end{array}$ & $\begin{array}{l}\text { Sustainable Society } \\
\text { Foundation }\end{array}$ & $x$ & $\mathrm{x}$ & - & $x$ & $x$ & - & $x$ \\
\hline $\begin{array}{l}\text { SENSOR (Sustainable } \\
\text { Impact Assessment Tool) } \\
(2008)\end{array}$ & $\begin{array}{l}\text { AB Projesi kapsamında, } \\
\text { Helming ve diğ. }\end{array}$ & $x$ & $x$ & $x$ & $\mathrm{x}$ & $x$ & $x$ & $x$ \\
\hline $\begin{array}{l}\text { PLUREL (20I0) Perı-Urban } \\
\text { Land Use Relatıonships } \\
\text { Strategies and Sustaına- } \\
\text { bılıty Assessment Tools } \\
\text { For Urban-Rural Lınkages, } \\
\text { Integrated Project }\end{array}$ & $\begin{array}{l}\text { AB Projesi kapsamında, } \\
\text { Kroll ve diğ. }\end{array}$ & $x$ & $x$ & $\mathrm{x}$ & $\mathrm{x}$ & - & - & - \\
\hline $\begin{array}{l}\text { European Green City Index } \\
\text { (2009) }\end{array}$ & Siemens & $x$ & $x$ & - & - & $x$ & - & $x$ \\
\hline Solutions (2010) & Echenique et.al. & $x$ & - & - & - & $x$ & - & - \\
\hline $\begin{array}{l}\text { UK Sustainable Cities } \\
\text { Index (2007) }\end{array}$ & Forum for the Future & $x$ & $x$ & $x$ & - & - & - & $x$ \\
\hline $\begin{array}{l}\text { China Urban Sustainability } \\
\text { Index }\end{array}$ & Urban China Initiative & $x$ & - & - & - & $x$ & $x$ & $x$ \\
\hline European Green City Tool & European Union & $x$ & $x$ & - & $x$ & $x$ & $x$ & $x$ \\
\hline $\begin{array}{l}\text { Urban Ecosystem Europe - } \\
\text { Informed Cities }\end{array}$ & $\begin{array}{l}\text { Ambiente Italia Institu- } \\
\text { to di Richerche }\end{array}$ & $x$ & $x$ & - & $x$ & $x$ & $x$ & $x$ \\
\hline $\begin{array}{l}\text { Urban Metabolism Frame- } \\
\text { work }\end{array}$ & $\begin{array}{l}\text { European Environmen- } \\
\text { tal Agency }\end{array}$ & $x$ & $x$ & $x$ & $x$ & $x$ & - & $x$ \\
\hline $\begin{array}{l}\text { Sustainable Cities Index } \\
\text { Ranking in Australia (2010) }\end{array}$ & $\begin{array}{l}\text { Australian Conservati- } \\
\text { on Foundation (ACF) }\end{array}$ & $x$ & $x$ & - & $x$ & - & - & - \\
\hline
\end{tabular}

ES sınıflandırmalarında ekosistemlerin sağladığı faydaları genel itibariyle kaynak sağlayıcı, düzenleyici ve sosyo-kültürel olarak nitelendirilebilecek üç temel başlıkta ele alınmaktadır. Düzenleyici servisler ekosistemlerin hava kalitesi, su ve toprak kaynakları, iklimle ilişkili olarak atmosferdeki düzenleyici işlevlerini tanımlayan servislerdir (Tezer vd, 20I5). CICES sınıflamasında bu servisler biyotanın iyileştirilmesi, ekosistemlerin iyileştirmesi, toprak kayıplarının engellenmesi, toprak formasyonunun korunması, su akışının iyileştirilmesi, hava akımının iyileştirilmesi, yaşam döngüsü ve gen havuzunun korunması, pestisit ve hastalık kontrolünün sağlanması, atmosferik içerik ve iklim düzenlemesi olarak tanımlanmıştır (Tablo 2).
Düzenleyici servisler; hava, su ve toprak gibi temel doğal kaynakların varlığının ve kalitesinin devamlılığını, iklim süreçlerinin dengeli bir şekilde gerçekleşmesini, su döngüsü ve küresel sıcaklık gibi kritik faktörlerin düzenlenmesini, biyoçeşitliliğin sürdürülebilmesini ve tüm ekolojik sistemin olası doğal veya antropojenik risklere karşı daha dayanıklı olmasını sağlamaktadır (Arneth vd. 2005, Chapin vd, 2005, Ahmed ve Osibanjo, 2005). Bu doğrultuda araştırma kapsamında mekânsal planların çevresel sürdürülebilirlik düzeylerinin değerlendirilmesinde düzenleyici servisler mekânsal kullanım türleriyle eşleştirilerek çevresel sürdürülebilirlik bileşenleri için bir "proxy'" niteliğinde kullanılmıştır.

\footnotetext{
' Bir başka ifadeyle, düzenleyici ekosistem servisleri çevresel sürdürülebilirliği temsil edebilecek bir arayüz olarak kullanılmıştır.
} 


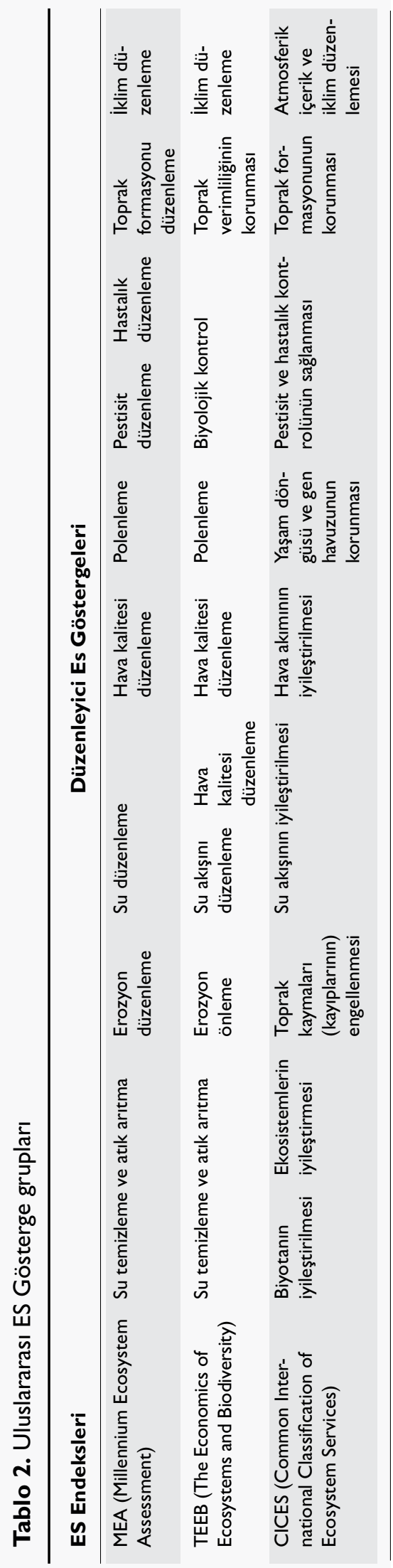

Bu kapsamda biyotanın ve ekosistemlerin iyileştirilmesi, pestisit ve hastalık kontrolünün sağlanması, yaşam döngüsünün ve gen havuzunun korunması ekosistem çeşitliliği ile; toprak kaymaları ve formasyonunun korunması toprak kalitesiyle; su akışının iyileştirilmesi su kalitesiyle; hava kalitesinin iyileştirilmesi ve atmosferik içerik düzenlemesi hava kalitesi ile doğrudan ilişkilidir (Tablo 3).

Kullanılan ES bileşenlerinin yönteme entegrasyonu mekânsal planlarda yer alan kullanım türlerinin matris yaklaşımı çerçevesinde puanlanmasıyla sağlanmıştır. Daha önce de belirtildiği üzere matris yaklaşımı ES potansiyelini belirlemeye çalışan birçok çalışmada kullanılmaktadır (Campagne ve Roche, 2018). Mekânsal kullanım türleri ile ilişkili olarak ortaya çıkan ES potansiyelinin analiz edildiği literatür örneklerinde, mekânsal kullanım türlerinden sağlanan servislerin ölçülen veya sahadan toplanan veriler üzerinden analiz edilmesi esas yaklaşım olarak kullanılmaktaysa da söz konusu verilerin istenilen kalite veya erişilebilirlikte olmaması nedeniyle bu servislerin uzman görüşlerine dayalı puanlamaya bağlı olarak değerlendirilmesi kullanılan yöntemlerden bir diğeridir (Burkhard vd, 2009, Burkhard vd, 2012, Jacobs vd, 2015). Nitekim veri eksikliğinin bulunduğu bölgelerde, farklı örnek alanlarda üretilmiş verilere dayalı kabuller; mekânsal kullanımın sağlayacağı fayda veya neden olacağı zararlarla ilgili karar verme süreçlerinde yeterli ve detaylı düzeyde yönlendirme sağlayabilmektedir (Sumarga, 20I5). Matris yaklaşımı ile arazi kullanım türleri ve ES’lerin eşleştirilmesi sağlanarak, her bir arazi kullanım türünün ES üretme kapasitesi alana özgü veri ve/veya uzman görüşleri kullanılarak değerlendirilmekte; 0 en düşük, 5 en yüksek puan olacak şekilde puanlandırılmaktadır (Burkhard vd. 2009, 2014, Jacobs vd, 2015). Tablo 4'te örnek bir puanlama çizelgesi yer almaktadır.

Ancak matris yaklaşımı mekânsal kullanımın yalnızca fayda tarafına odaklanmakta ve arazi kullanım türünün sağlayabileceği ES potansiyelini ortaya koymaktadır. Bu nedenle de mekânsal kullanımın yarattığı olumsuz etkiler, matris yaklaşımının kullanım alanı gereği, parametreler arasında yer almamaktadır. Buna göre matris yaklaşımında bir sanayi alanına " 0 " puan atanmakta, yani sanayi alanının ES potansiyeli olmadığı kabul edilmektedir. Oysa antropojenik etkilerin gerek ekosistem nitelikleri gerekse sağlanan faydalar üzerinde olumsuz yönde de etkileri bulunmaktadır. Bu sebeple mekânsal kullanımın çevresel sürdürülebilirlik boyutuyla ele alınabilmesi için neden olunan zararların da dikkate alınması gerekmektedir. Bu çerçevede mekânsal planların çevresel sürdürülebilirlik düzeyinin ölçülebilmesi amacıyla; matris yaklaşımı geliştirilerek mekânsal kullanımın neden olduğu olumsuz etkiler de dikkate alınmış ve Burkhard vd.'nin (2009) çalışmasındaki puan aralığı “(0) - (+5)” ten “(-5) ve (+5)” puan aralığına genişletilmiştir. Böylelikle çevresel sürdürülebilirlik (ÇS) potansiyeli değerlendirme tablosu elde edilmiştir. Negatif değerlerin matris yaklaşımına entegrasyonunun analitik 
Tablo 3. Çevresel sürdürülebilirlik ile ES türlerinin entegrasyonu

\begin{tabular}{|c|c|c|c|c|c|c|c|c|c|}
\hline \multirow[b]{2}{*}{$\begin{array}{l}\text { Çevresel sür- } \\
\text { dürülebilirlik } \\
\text { bileşeni }\end{array}$} & \multicolumn{9}{|c|}{ Düzenleyici Es Göstergeleri (CICES Çerçevesi) } \\
\hline & $\begin{array}{l}\text { Biyotanın } \\
\text { iyileştiril- } \\
\text { mesi }\end{array}$ & $\begin{array}{l}\text { Ekosis- } \\
\text { temerin iyi- } \\
\text { leştirmesi }\end{array}$ & $\begin{array}{l}\text { Toprak } \\
\text { kaymaları } \\
\text { (kayıpları- } \\
\text { nın) engel- } \\
\text { lenmesi }\end{array}$ & $\begin{array}{l}\text { Su } \\
\text { akışının } \\
\text { kontrolü }\end{array}$ & $\begin{array}{l}\text { Hava } \\
\text { akışının } \\
\text { kontrolü }\end{array}$ & $\begin{array}{l}\text { Yaşam } \\
\text { döngüsü } \\
\text { ve gen } \\
\text { havu- } \\
\text { zunun ko- } \\
\text { runması }\end{array}$ & $\begin{array}{l}\text { Pestisit ve } \\
\text { hastalık } \\
\text { kontrolü }\end{array}$ & $\begin{array}{l}\text { Toprak } \\
\text { formasyon } \\
\text { ve içeriği- } \\
\text { nin iyileşti- } \\
\text { rilmesi }\end{array}$ & $\begin{array}{l}\text { Atmosfe- } \\
\text { rik içerik } \\
\text { ve iklim } \\
\text { düzenle- } \\
\text { mesi }\end{array}$ \\
\hline Hava kalitesi & & & & $x$ & $x$ & $x$ & & & $x$ \\
\hline Su kalitesi & & & & $x$ & & $x$ & $x$ & & $x$ \\
\hline Toprak kalitesi & & & $x$ & & & $x$ & $x$ & $x$ & $x$ \\
\hline $\begin{array}{l}\text { Ekosistem } \\
\text { çeşitliliği }\end{array}$ & $x$ & $x$ & & & & $x$ & $x$ & $x$ & $x$ \\
\hline
\end{tabular}

Tablo 4. Mekânsal kullanımın (MK) sağladığı Ekosistem Servisleri (ES) potansiyeli

\begin{tabular}{ccccccc}
\hline & ESI & ESI & ES 3 & ES 4 & ES 5 & $\begin{array}{c}\text { Toplam } \\
\text { Es Puanı }\end{array}$ \\
\hline MKI & 5 & 3 & 5 & 3 & I & 17 \\
MK2 & 4 & 4 & 3 & 3 & I & 15 \\
MK 3 & 0 & 2 & I & I & 0 & 4 \\
\hline
\end{tabular}

Tablo 5'te sunulmaktadır. Bu kapsamda Tablo 5'te yer alan ÇS bileşenleri Tablo 4'te yer alan ES bileşenleri ile aynı olduğu varsayımından yola çıkarak puanlama sistemi incelendiğinde, herhangi bir mekânsal kullanıma bağlı ortaya çıkan ÇS puanı pozitif veya negatif puanlar alabilmektedir. MK $^{3}$ 'ün "kentsel alan" olduğu düşünüldüğünde kentsel alanların ES sağlama potansiyeli az olduğundan ve $\mathrm{MK}^{3}$ 'ün su akışının iyileştirilmesine yönelik potansiyelinin "0" değeri aldığı görülmektedir (Tablo 4). Ancak diğer yandan $\mathrm{MK}^{3}$ 'ün ÇS potansiyeline bakıldığında, kentsel alanların su akışındaki olumsuz etkilerine bağlı olarak "-3" değeri almakta; böylelikle negatif değerler de modele entegre edilmektedir (Tablo 5).

Özetle Tablo 5 ile ifade edilen ÇS matrisi, mekânsal planlarda tanımlı bazı fonksiyonların (orman, sulak alanlar, mera vb.) ES üretimindeki rolleri; bazı fonksiyonların (sanayi alanları, yoğun yerleşim alanları vb.) ise ekosisteme yaptıkları olumsuz etkileri temel alınarak puanlamasıyla oluşturulmuştur. Puanlamada pozitif değerler ES'lere; negatif değerler ise ekosistem etkilerine karşlık gelmektedir. Bu kapsamda bir mekânsal kullanım (MK) türünün çevresel sürdürülebilirlik düzeyi Denklem I ile tanımlanmaktadır.

$M K$ Sürdürülebilirlik potansiyeli $=$ Ekosistem servisleri + Ekosistem etkileri

Mekânsal kullanım türünün sağladığı fayda veya neden olacağı negatif etkiler; söz konusu kullanımın alansal büyüklüğü ile doğru orantılı olacaktır. Örneğin kentsel yeşil alanların büyüklüğü ile karbon tutma kapasitesi ve polenleme seviyesinde doğrusal bir orantı olduğu tespit edilmekte (Grafius vd, 2018) ve orman alanları arttıkça karbon tutma kapasitesinin de arttığı görülmektedir (http://www.fao.org/docrep/005/ac836e/ AC836E03.htm). Bu noktada mekânsal kullanımın çevresel sürdürülebilirlik potansiyelinin analizine alansal büyüklük faktörü entegre edilmiş; mekânsal kullanımların alan büyüklükleri 100 hektar cinsine dönüştürülerek hesaplanmıştır. Her bir mekânsal kullanım türü için Denklem 2 kullanılarak alan hesaplamaları gerçekleştirilmiştir.

$M K^{i}$ Sürdürülebilirliğ $i=M K^{i}$ Alanı $\times \sum_{j=1}^{n} M K$ Sürd.Potensiyeli ${ }^{i, j}$

Yukarıdaki denklemde "i" mekânsal kullanım türünün numarasını; "j" ÇS bileşeni numarasını; " $n$ " toplamda bulunan ÇS bileşeni sayısını ifade etmektedir. Bir mekânsal planın farklı kullanım türlerini içermesi nedeniyle, mekânsal planın toplam ÇS değeri Denklem 3'de yer aldığı şekilde hesaplanmaktadır.

Mekansal Plan Sürdürülebilirliğ $i=\sum_{i=1}^{m} M K^{\imath}$ Sürdürülebilirliği

Mekânsal planın ÇS değerinin hesaplanması için geliştirilen fonksiyonların kent plancıları ve/veya karar vericiler için uygulanabilir olduğunun ve tasarlanan planın sürdürülebilirliğe katkısı olup olmadığının anlaşılabilmesi mekânsal plan performansının bir referans veriyle karşılaştırılması gerektirmektedir. Bu noktada, mekânsal planın uygulandığı alanın ÇS düzeyini olumsuz etkilememesi için o bölgedeki mevcut arazi kullanımın ekolojik limitlerini aşmaması gerekliliğinden yola çıkarak; mekânsal planın (MP) ÇS düzeyiyle, mevcut arazi kullanım (AK) durumunun ÇS düzeyi karşılaştırılması gerekmekte; uygulama alanında çevresel sürdürülebilirliğin sağlanması için MP'ye ait ÇS düzeyi ile AK'ya ait ÇS düzeyi arasında farkın pozitif sonuçlar üretmesi gerekmektedir (Denklem 4).

MP.Sürdürülebilirlik Performansı $=$ MP Sürd.Seviyesi - AK Sürd.Seviyesi 
Tablo 5. Güncellenmiş ÇS potansiyeli örnek değerlendirme tablosu

\begin{tabular}{lcccccc}
\hline & ÇSI & ÇSI & ÇS 3 & ÇS 4 & ÇS 5 & $\begin{array}{c}\text { Mekânsal Kullanım Türü Toplam } \\
\text { Çevresel Sürdürülebilirlik Puanı }\end{array}$ \\
\hline MKI & 5 & 3 & -5 & 3 & 1 & 7 \\
MK2 & 4 & -4 & 3 & 3 & -1 & 5 \\
MK 3 & -3 & -2 & -3 & 1 & 2 & -5 \\
& & & & $\begin{array}{c}\text { Planın Toplam } \\
\text { ÇS Puanı }\end{array}$ \\
\hline
\end{tabular}

\section{Yazılım Genel Özellikleri}

Bu araştırma ile geliştirilen yöntemde iki farklı mekânsal veri (plan durumu ve mevcut arazi kullanımı) girdi olarak analiz edilmekte ve geliştirilen yöntemin CBS yazılımıyla uygulanması hedeflenmektedir. Yazılımın kullanılabilirliğini yaygınlaştırmak üzere mekânsal kullanımların sınıflandırılmasında uluslararası geçerliliği olan (EEA, 2012) Corine Arazi Örtüsü sınıflaması temel alınmış ve literatür örneklerinde de uygulandığı gibi (Burkhard vd, 2009; Jacobs vd, 2015; Herrman vd, 20I5; Stroll vd, 2015) geliştirilen yazılımda (EnSAT) tüm girdilerin Corine Arazi Örtüsü sınıflarıyla eşleştirilmesi mümkün kılınmıştır.

Mekânsal kullanım verilerinin Corine Arazi Örtüsü sınıfları temelinde kategorize edilmesi, literatürde matris yaklaşımı kullanılarak yapılmış ES analizi çalışmalarında özellikle bölgesel ve ulusal ölçeklerde geçerli sonuçlar elde edilmesini sağlamıştır (Martinez-Harms ve Balvanera, 20I2). Bu araştırma kapsamında da aynı yaklaşımın kullanılarak özellikle üst ölçek mekânsal planların çevresel sürdürülebilirlik performansının analiz edilebileceği öngörülmektedir.

Bu kapsamda araştırmada geliştirilen yöntem ve EnSAT yazılımı öncelikli olarak üç (3) aşamalı bir teste tabi tutularak, elde edilen sonuçların doğruluk ve güvenilirliği test edilmiştir. Bunun için ilk aşamada Birleşmiş Milletler Sürdürülebilir Kalkınma Hedefleri (SDG) temel alınarak belli ülkelerin çevresel sürdürülebilirlik analizi yapılmış ve analiz sonuçları SDG Endeksi sonuçları ile karşılaştırılmıştır. İkinci aşamada ise EnSAT yazılımının geliştirilen yöntem adımlarını uygulama doğruluğu ve geçerliliği test edilmiş ve son olarak yazılım sonuçları makullük testlerine tabi tutulmuştur. Bu testlere ait detaylar EkI'de sunulmaktadır.

CBS tabanlı EnSAT yazılımı, araştırmada geliştirilen yöntem algoritmasını kullanarak sürdürülebilirlik performansı sonuçlarının haritalarla görselleştirilmesini sağlamak üzere geliştirilmiştir. Böylelikle bir uygulama alanı için önerilen mekânsal planın ÇS düzeyi ile o alandaki mevcut arazi kullanımının ÇS düzeyi mekânsal boyutta karşılaştırılabilir hale getirilmekte; plan kararlarının uygulama alanında ÇS düzeyini nasıl ve nere- de etkileyebileceği belirlenebilmektedir.

Uygulama alanına ilişkin mekânsal plan verisi ve mevcut arazi kullanım verisini temel girdi olarak kullanan EnSAT yazılımındaki ilk adım kullanıcı tarafından mekânsal kullanım türlerinin ve her bir kullanım türüne ait alansal büyüklüklerin betimlenmesidir. Bunun için yazılımda girdi olarak kullanılan veriler Corine Arazi Örtüsü sınıflarıyla eşleştirilmekte; böylelikle yazılımda standart bir taksonomi kullanılması sağlanarak mekânsal planlarda yer alan çok çeşitli fonksiyonlar ile mevcut arazi kullanımı/arazi örtüsü arasındaki farklılıklar giderilmektedir. Bu eşleştirmelerin nasıl gerçekleştirildiğine dair Corine Arazi Örtüsü verisi ve İstanbul 2009 Çevre Düzeni Planı'ndaki bazı mekânsal fonksiyonlar kullanılarak yapılan dönüşümler Tablo 6'da örnek olarak sunulmaktadır.

EnSAT yazııımının ikinci adımı mekânsal planların ve mevcut arazi örtüsü/arazi kullanımının ÇS düzeylerinin hesaplanabilmesi için ÇS puanlarının tanımlanması ve yazııım arayüzü ile girişlerinin yapılmasıdır. Bunun için yazılım algoritması içinde kodlanmış olan ÇS matrisi kullanıcılara güncelleme imkânı sunacak şekilde tanımlanmıştır. Böylelikle EnSAT yazııımının farklı uygulama alanlarında uzman görüşlerine bağlı olarak belirlenebilecek farklı ÇS matrisi puanlarının hesaplamalarda kullanılabilmesi mümkün hale getirilmiştir.

İ̧̧leyiş diyagramı Şekil 2'de yer alan EnSAT yazılımı ile mekânsal kullanım türleri, bu türlere ait ÇS puanları ve alansal büyüklük verileri ile yöntem kısmında belirtilen işleyiş doğrultusunda hesaplamalar yapılmakta ve sonuçlar grafik ve harita gösterimleriyle kullanıcılara sunulmaktadır. Böylelikle mekânsal planların ÇS düzeylerine ilişkin somut sonuçlar, kullanıcılara sayısal ve mekânsal değerlendirme ve yorumlama imkânı sağlamaktadır.

EnSAT yazılımı ".net framework 4.6" altyapısı kullanılarak C\# dilinde geliştirilmiştir. Yazılımın kurulum dosyasındaki eşleştirme tablosunu okuma ve sisteme entegre edilen haritada gösterimi sağlamak için "dotspatial" kütüphanesi”nden faydalanımıştır (https://dotspatial.codeplex.com/) ve geniş kullanıcı kesimine hizmet etmek üzere mekânsal verileri ESRI shp formatında kullanmaktadır. 
Tablo 6. Çevre düzeni planı ve corine arazi kullanım örtüsü eşleştirmesi

\begin{tabular}{cc}
\hline Çevre Düzeni Planı Fonksiyonları & Corine Arazi Kullanım Fonksiyonları \\
\hline Baraj-Göletler & Su kütleleri \\
\hline Doğal karakteri korunacak alanı & Doğal yeşil alanlar \\
Gelişim ve yoğunluğu kontrol altında tutulacak olan alan & Süreksiz kentsel alan \\
Mera & Mera \\
Kentsel alan & Sürekli kentsel alan \\
Organize sanayi bölgesi & Sanayi ve ticari alan \\
Orman alanı & Geniş yapraklı orman, İ̆ne yapraklı orman, karışık tür orman \\
Kıyı ve sahil kumulları & Sahil, kumul ve plajlar \\
Sanayi alanı & Endüstriyel-ticari kullanım alanı \\
Tarım arazisi & Tarım arazisi
\end{tabular}

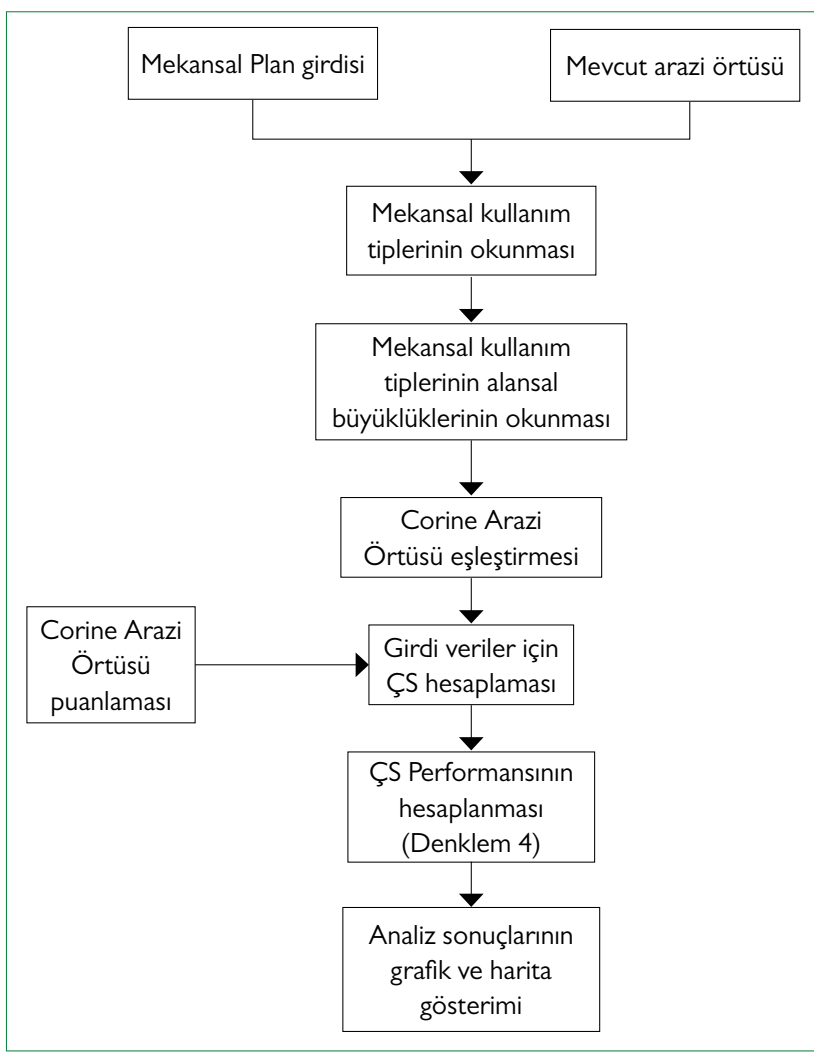

Şekil 2. Yazılım akış diyagramı

\section{Uygulama}

Yazılım geliştirme adımlarının tamamlanması ardından; örnek bir uygulama geliştirme amacıyla çevresel sürdürülebilirlik performansı tespit edilmek üzere İstanbul metropoliten alanı içinden seçilen bir bölgenin (Şekil 3) 2009 yılı İstanbul Çevre Düzeni Planı ile aynı bölgeye ait 2006 yıllı Corine Arazi Örtüsü verisi karşılaştırılmıştır. Bu karşılaştırma için EnSAT'e entegre edilen puanlama değerleri İstanbul Büyükşehir Belediyesi (IBB) tarafından yürütülen İ Çevre Düzeni Planı'nın (ÇDP)

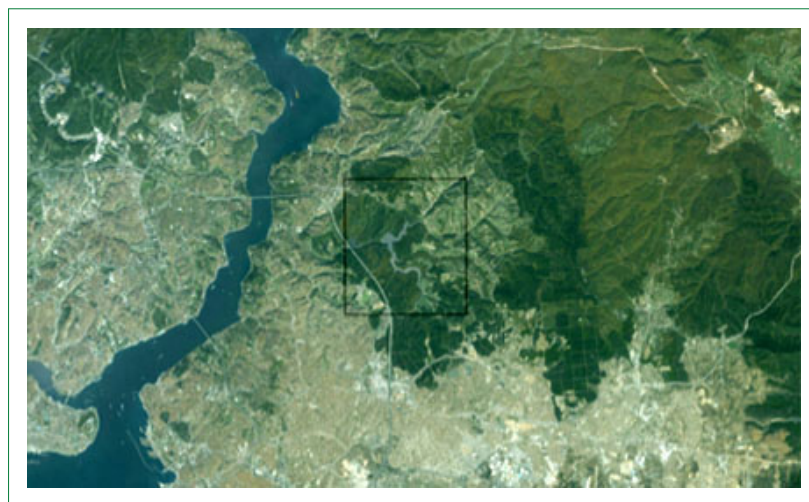

Şekil 3. Seçili test alanı

güncellenmesi çalışması (2017) kapsamında 72 farklı paydaşla yapılmış anket sonuçlarından derlenmiştir.

Karşılaştırma işleminin gerçekleştirilebilmesi için öncelikli olarak veriler yazılıma girilmekte ve mekânsal kullanım türleri ile Corine Arazi Örtüsü sınıfları eşleştirilmektedir. Bunun üzerine EnSAT'a girişleri yapılan seçili bölge verilerine ait mekânsal kullanım türlerinin skorları hesaplanmaktadır. Bu işlemlerin ardından EnSAT bünyesinde plan ile arazi kullanım verisinin sürdürülebilirlik değeri çubuk veya çizgi grafik olarak görselleştirilmektedir. Bu karşılaştırma sonucunda her iki veriseti için Şekil 4'te yer alan grafik oluşmuştur. Bu grafikte sütunlar mekânsal kullanım türü; satırlar ise çevresel sürdürülebilirlik skorunu göstermektedir.

Buna ek olarak grafik gösteriminin altında yer alan seçenekler ES göstergelerinden oluşmakta olup; ES türlerine ait skorlar grafiğe yansıtılmaktadır. Böylece mekânsal kullanım türüne bağlı olarak hangi ES göstergesinde ne şekilde değişiklik olduğu da anlaşılır olmaktadır. Ayrıca bu grafikte yer alan "toplam” çizgileri de arazi kullanımı ve planın toplam puanlarını grafik üzerinde göstermektedir. Bu sayede planın toplam çevresel sürdürülebilirlik puanının mevcut duruma göre olan farkı da anlaşılabilmektedir. 


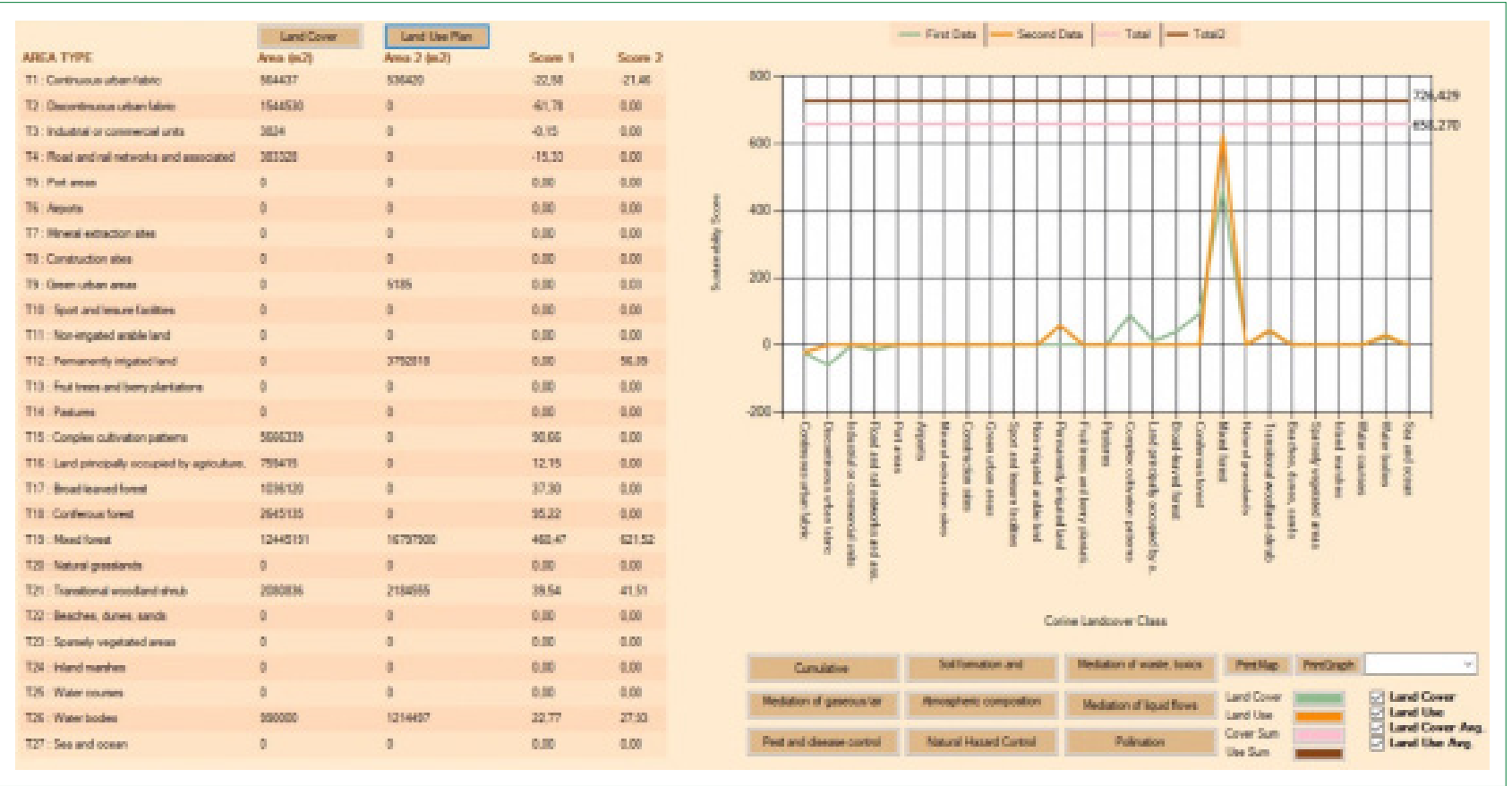

Şekil 4. Veri girişlerinden sonra oluşan grafik gösterimi

Plan ve arazi kullanım verisi ayrıca "harita" sekmesinde "Google Maps" servisinden faydalanılarak temin edilen harita üzerine işlenmektedir. Buradaki gösterim sisteme girişi yapılan verilerin skorları baz alınarak yapılmaktadır. Harita görselleştirmelerine ilişkin görseller Şekil 5 ve 6 'da sunulmaktadır. Gösterimde yeşil-kırmızı arası skalada sürdürülebilirlik değeri yüksekten-düşüğe değişmektedir.

Gerçekleştirilen analiz sonucunda, 2009 yılı ÇDP'nin; altlık olarak temel aldığı 2006 yılına ait Corine Arazi Örtüsü verisinden daha yüksek skor ürettiği tespit edilmiştir. Şekil 4'te verilen grafikten de anlaşılacağı üzere bundaki en büyük etmen orman alanı büyüklükleri arasındaki farktır. Benzer şekilde Corine Arazi Örtüsü verisinde meskûn alanlar daha fazla yer tutmakta ve dolayısıyla ÇDP'ye göre daha düşük ÇS skoru üretmektedir. Sonuçta bu iki durumun etkisiyle seçili bölge için ÇDP ileriye dönük daha sürdürülebilir bir mekânsal kullanım öngörmektedir.

\section{Sonuç}

Sürdürülebilir mekânsal planlama üzerine yapılan çalışmalarda, ekolojik yapının korunması ve devamlılığının sağlanmasına yönelik yaklaşımların mekânsal plan üretimi süreçlerinde giderek artan bir rol üstlenmesine rağmen mekânsal planların çevresel sürdürülebilirlik düzeylerinin belirlenmesi ve üretilen mekânsal planların uygulama alanındaki çevresel sürdürülebilirlik düzeyini nasıl etkileyeceğine ilişkin bütüncül analitik yöntemlerin bulunmadığı görülmektedir. Bu çalışmada üst ölçek mekânsal planların (örn: bölge planı, havza yönetim planı,

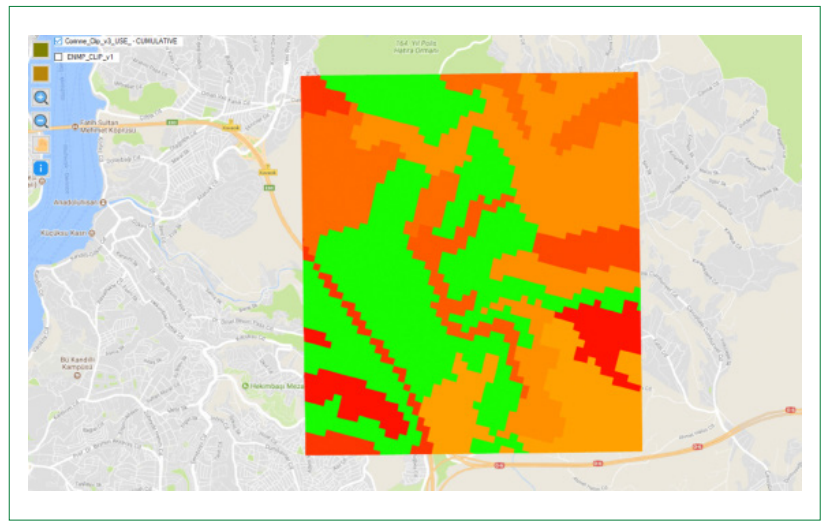

Şekil 5. Corine Arazi Örtüsü (2006) verisine ait çevresel sürdürülebilirlik haritası gösterimi

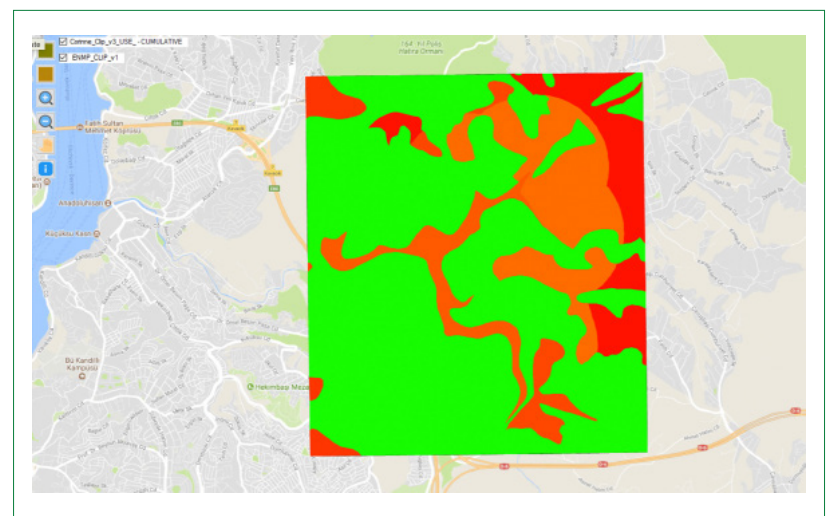

Şekil 6. İstanbul ÇDP (2009) verisine ait çevresel sürdürülebilirlik haritası gösterimi 
çevre düzeni planı vb.) uygulamaya geçilmeden önce nasıl bir çevresel etki yaratacağı ve çevresel sürdürülebilirliği ne şekilde değiştirebileceğine ilişkin özgün bir yaklaşım geliştirilmiş ve bu yaklaşım kullanıcı dostu bir yazılımla (EnSAT) entegre edilmiştir. Böylelikle başta plancılar olmak üzere karar vericiler için rehber niteliği taşıyabilecek; üretilen mekânsal planların ekosistemler ve ES açısından nasıl sonuçlar doğurabileceğine ilişkin analitik bir süreç tariflenmiştir.

Geliştirilen yöntem iki temel varsayıma dayanmaktadır. Birinci varsayım ekosistemler açısından bir mekânsal planın hem fayda sağlama hem de zarara neden olma yönünde bir içeriğe sahip olabileceği kabulünden yola çıkarak; çevresel sürdürülebilirlik için mekânsal planın fayda/zarar ilişkisinin mutlaka fayda yönünde olması gerekliliğidir. Bu kapsamda bir mekânsal plan hem kendi içinde doğanın taşıma kapasitesini aşmamalı; hem uygulandığı alandaki mevcut ekolojik kaliteyi daha üst seviyeye taşımalıdır. İkinci varsayım ise geliştirilen yöntemin mekânsal planın öngörüldüğü haliyle uygulandığı, yani mekânsal planla tam uyumlu olarak uygulamaların yürütüleceği kabulüne dayanmaktadır. Gerçekte ise planın uygulanmalarında sorunlar ortaya çıkabilmekte; plan kararları ve uygulamalar çelişebilmektedir. Bu tür dışsal etkileri analitik olarak modellemek mümkün olmadığı için; çalışmanın kapsamı dışında bırakılmıştır.

Araştırma, ES tabanlı matris yaklaşımı temelinde geliştirilen yöntemle çevresel sürdürülebilirlik kavramı değerlendirmekte; bunun için mekânsal planların çevresel sürdürülebilirlik performanslarını bir araç olarak kullanmaktadır. Böylece bir mekânsal planın sürdürülebilirlik düzeyi ile uygulama alanına olan etkisi ve/veya katkısı analitik olarak ölçülebilir hale gelmektedir.

Uygulanan yöntemin yaygınlaştırılabilmesi için CBS tabanIı EnSAT yazılımı geliştirilmiştir. EnSAT yazılımıyla, mekânsal planın mevcut arazi kullanımından nasıl farklılaştığı grafik gösterim ve haritalama teknikleriyle net bir şekilde ortaya konulmaktadır. Ayrıca bu çıktılar karar verici ve uygulayıcıları için hangi mekânsal kullanım türlerine önem ve öncelik verilmesi gerektiği ya da hangi ES'nin çevresel sürdürülebilirlik açısından hassas ve kritik olduğu konusunda rehber niteliğindedir. Günümüzdeki sürdürülebilirlik analizlerinin çoğunda mevcut durumun ne kadar sürdürülebilir olduğuna dair değerlendirmeler yapılmaktayken; bu araştırma ile geleceğe dair geliştirilmiş öngörülerin ve planların analitik süreçler içinde üretilmesi mümkün kılınmakta ve bu sayede kentsel gelişimin yönlendirilmesinde; ekolojik kalitenin korunması ve sürdürülmesine yönelik temel bir ihtiyaç karşılanmaktadır.

\section{Gelecek Çalışmalar}

Araştırmayla geliştirilen yöntemin temel hedefi ekolojik işlevler açısından daha sürdürülebilir mekânsal planların üretil- mesine katkı sağlamak olduğundan, ileriki dönemlerde yöntem içeriğinde parametrelerin çeşitlendirilerek geliştirilmesi önemli bir husustur. Bu noktada mekânsal kullanımların ekosistemlerde yarattığı parçalanmışlığın (fragmantasyon) niteliği, ekosistemlerin fayda sağlama potansiyeli açısından önemli parametrelerden biridir ve ES kapasitelerine ilişkin ağırlıkların da yönteme dâhil edilmesiyle çevresel sürdürülebiliriğine ilişkin daha hassas hesaplamalar yapılabilecektir. Bu sayede hem mekânsal kullanımın ekolojik sürece etkisi veya katkısı, hem mevcut mekânsal kullanımların bütünlüğü veya parçacıllığı, hem de sağlanan ES’lerin önem ağırlıkları bütünleşik olarak değerlendirilebilecek, kapsayıc bir modelin oluşturulmasıyla EnSAT yazılımı geliştirilecektir. Ayrıca EnSAT yazılımının CBS temelli yaygın olarak kullanılan yazılım platformları (ArcGIS, QGIS) vb.) ile uyumlaştırılarak bir eklenti haline dönüştürülmesi hedefler arasındadır. Böylelikle planların ekolojik yapı ve ekosistemlerce sunulan faydalar üzerindeki etkisinin karar destek aracı olarak mekânsal planlama sürecinde kullanılmasında ve mekânsal planların performanslarının ölçülmesinde etkin şekilde katkı sağlayacağı öngörülmektedir.

\section{Teşekkür}

$\mathrm{Bu}$ çalışmanın gerçekleştirilmesinde yorum ve önerileriyle katkıda bulunan Prof. Dr. Ergin TARI'ya, Doç.Dr. Doruk ÖZÜGÜL'e, detaylı değerlendirmeleriyle yayının mevcut haline kavuşmasında büyük bir emek ve özveri gösteren Şehir Plancısı Arş. Gör. Nüket İpek Çetin'e ve son olarak da maddi imkân sağlayarak bu araştırmayı destekleyen Marmara Belediyeler Birliği'ne teşekkürlerimizi sunarız. 


\section{KAYNAKLAR}

Ahmed, M.T. ve Osibanjo, O. (2005). Waste Processing and Detoxification in Hassan, R., Scholes, R. ve Ash, N., eds, Ecosystems and Human Well-being: Current State and Trends, 1, 419 - 438, Island Press, Washington DC

Alberti, M., Measuring urban sustainability (1996). Environmental Impact Assessment Review, 16 (4-6), 381-424.

Arneth, A., Barratt, D., Cassman, K., Christensen, T., Cornell, S., Foley, J., Ganzeveld, L., Thomas, H., Houweling, S.,, Scholze, M., Joos, F., Kohfeld, K., Manizza, M., Ojima, D., Prentice, I.C., 1 Schaaf, C., Smith B., Tegen, I.,Thonicke, K., Warwick, N. (2005). Climate and Air Quality in Hassan, R., Scholes, R. ve Ash, N., eds,Ecosystems and Human Well-being: Current State and Trends, 1, 357 - 384, Island Press, Washington DC.

Arrow, K., Bolin, B., Costanza, R., Dasgupta, P., Folke, C., Holling, C. S., Jansson, B.O., Levin, S., Maler, K.G., Perrings, C., Pimentel, D., (1995), Economic growth, carrying capacity, and the environment, Ecological Economics, 15, (2), 91-95.

Böhringer, C., Jochem, P. E. P. (2007). Measuring the immeasurable, A survey of sustainability indices, 63 (1991), 1-8.

van den Berg, M., Wendel-Vos, W., van Poppel, M., Kemper, H., van Mechelen, W., Maas, J., (2015). Health benefits of green spaces in the living environment: A systematic review of epidemiological studies, Urban Forestry \& Urban Greening, 14 (4), 806- 816, https://doi.org/10.1016/j. ufug.2015.07.008.

Burkhard, B., Kroll, F., Müller, F., Windhorst, W., Burkhard, B., Kroll, F,, Windhorst, W. (2009). A Concept for Land-Cover Based Assessments Landscapes' Capacities to Provide Ecosystem Services, http://doi. org/10.3097/LO.200915

Burkhard, B., Kroll, F., Nedkov, S., Müller, F., (2012). Mapping ecosystem service supply, demand and budgets Ecological Indicators, 21, 17 29, https://doi.org/10.1016/j.ecolind.2011.06.019

Burkhard, B., Kandziora, M., Hou, Y., Müller, F. (2014). Ecosystem service potentials flow, and demands-concepts for spatial localization, indication, and quantification. Landscape Online. http://doi.org/10.3097/LO.201434

Cato, M. S., (2009).: An Introduction to Theory, Policy and Practice. London, Earthscan

Campagne C. ve Roche P., (2018). May the matrix be with you! Guidelines for the application of expert-based matrix approach for ecosystem services assessment and mapping. One Ecosystem 3: e24134. https://doi. org/10.3897/oneeco.3.e24134

Chapin III, F.S., Dirzo, R., Kitzberger, T., Gemmill, B., Zobel, M.,Vila, M., Mitchell, C., Wilby, A., Daily, G.C., Galetti, M., Laurance, W.F., Pretty, J., Naylor, R., Power, A. ve Harvell, D. (2005). Biodiversity Regulation of Ecosystem Services in Hassan, R., Scholes, R. ve Ash, N., eds, Ecosystems and Human Well-being: Current State and Trends Say1 1, 243 - 269, Island Press, Washington DC.

Chen, L., Yang, X., Chen L., Li L., (2015). Impact assessment of land use planning driving forces on environment, Environmental Impact Assessment Review, 55, (26-135), https://doi.org/10.1016/j.eiar.2015.08.001.

de Groot, R. (2006). Function-analysis and valuation as a tool to assess land use conflicts in planning for sustainable, multi-functional landscapes. Landscape and Urban Planning 75, 175-186.

Colding, J., (2011). The role of ecosystem services in contemporary urban planning. J. Niemelä, (ed.), Urban Ecology: Patterns, processes and applications (s.228-237). Oxford, Oxford University Press.

Costanza, R., D'Arge, R., de Groot, R.S., Farber, S., Grasso, M., Hannon, B., Limburg, K., Naeem, S., O’Neill, R.V., Paruelo, J., Raskin, R.G., Sutton, P. \& M. van den Belt (1997). The value of world's ecosystem services and natural capital. Nature 387, 253-260. doi:10.1038/387253a0

European Environment Agency, (2006)., Corine Land Cover Dataset and Report, http://land.copernicus.eu/pan-european/corine-land-cover, Son erişim tarihi: 01.11.2017

Forman, Richard T., (1995). Land Mosaics: the ecology of landscapes and regions: Land Mosaics, Cambridge, Cambridge University Press.

Grafius, D.R., Corstanje, R, ve Harris, J.A., Landscape Ecology (2018) 33:
557. https://doi.org/10.1007/s10980-018-0618-z

Grossmann W.D., Bellot J. (1999). Systems Analysis As a Tool for Rural Planning. Bellot J. (eds) Rural Planning from an Environmental Systems Perspective. Springer Series on Environmental Management. New York, Springer

Haila, Y., (2002). Scaling environmental issues: problems and paradoxes, In Landscape and Urban Planning, 61 (2-4), 59-69.

Haines-Young, R., ve Potschin M., (2013). Common International Classification of Ecosystem Services (CICES): consultation on version 4

Hermann, A., Kuttner, M., Hainz-Renetzeder, C., Konkoly-Gyuró, E., Tirászi, A., Brandenburg, C., Allex, B., Ziener, K., Wrbka, T., (2014) Assessment framework for landscape services in European cultural landscapes: An Austrian Hungarian case study, Ecological Indicators, 37 (A), 229-240, https://doi.org/10.1016/j.ecolind.2013.01.019.

EEA Framework Contract No EEA/IEA/09/003., August-December 2012. URL: http://cices.eu/ (2013)

Helming K., Perez-Soba M., Tabbush P. (Ed) (2008). Sustainability Impact Assessment of Land Use Changes

Hersperger, A.M., Mueller, G., Knöpfel, M., Siegfried, A., Kienast, F., (2017). Evaluating outcomes in planning: Indicators and reference values for Swiss landscapes, Ecological Indicators, 77, 96-104, https://doi. org/10.1016/j.ecolind.2017.02.004.

İstanbul Büyükșehir Belediyesi, (2009)., Çevre Düzeni Plan Raporu, İstanbul İstanbul Büyükşehir Belediyesi, (2017)., Çevre Düzeni Planı Gelişme Raporu, (Basılmamış Çalışma)

Jacobs, S., Burkhard, B., Van Daele, T., Staes, J., Schneiders, A. (2015). “The Matrix Reloaded": A review of expert knowledge use for mapping ecosystem services. Ecological Modelling. https://doi.org/10.1016/j.ecolmodel.2014.08.024

Jacobs, S., ve Burkhard, B. (2017). Applying expert knowledge for ecosystem services-quantification. Mapping Ecosystem Services, 142-146.

Kışlalıoğlu, M. ve Berkes, F., (2007). Çevre ve ekoloji. Remzi Kitapevi, İstanbul.

Leitao, A. B., Ahern, J. (2002). Applying landscape ecological concepts and metrics in sustainable landscape planning. Landscape and Urban Planning, 59, 65-93.

Martínez-Harms, M.J., ve Balvanera, P., (2012). Methods for mapping ecosystem service supply: a review, International Journal of Biodiversity Science, Ecosystem Services \& Management, 8:1-2, 17-25.

Mori, K., ve Christodoulou, A. (2012). Review of sustainability indices and indicators: Towards a new City Sustainability Index ( CSI ). Environmental Impact Assessment Review, 32(1), 94-106. http://doi. org/10.1016/j.eiar.2011.06.001

Millennium Ecosystem Assessment, (2005). Ecosystems and Human Wellbeing: Synthesis. Island Press, Washington DC.

Niemelä, J., Sanna-Riikka, S., Söderman, T., Kopperoinen, L., Yli-Pelkonen, V., Väre, S., Kotze, J. (2010). Using the ecosystem services approach for better planning and conservation of urban green spaces: A Finland case study. Biodiversity and Conservation. 19 (11), 3225-3243, https://doi. org/10.1007/s10531-010-9888-8

Orishimo, I., (1982) Urbanization and Environmental Quality. Londra, Kluwer:Nijhoff

Özcan K., (2016). Kent Planlamada Sürdürülebilirlik Gündemi: Bir Kavramsallaştirma Denemesi Eurasscience Journals, 4 (2): 7 - 17.

Pauleit, S. ve Duhme, F., (2000). Assessing the environmental performance of land cover types for urban planning. Landscape and Urban Planning, 52, 1-20.

Palamariu, M., Ildiko T., (2016). Land Use Planning Strategies for Shaping a Sustainable City; International Multidisciplinary Scientific GeoConference : SGEM : Surveying Geology \& mining Ecology Management; Sofia Vol. 3, : 303-310. Sofia: Surveying Geology \& Mining Ecology Management (SGEM).

Perminova T., Sirina N., Laratte B., Baranovskaya N., Rikhanov L., (2016). Methods for land use impact assessment: A review. Environmental Impact Assessment Review 60, 64-74.

Seasons, M., (2003). Monitoring and evaluation in municipal planning: Con- 
sidering the realities, Journal of the American Planning Association, 69 (4), 430-440. DOI: 10.1080/01944360308976329

Stoll, S., Frenzel, M., Burkhard, B., Adamescu, M., Augustaitis, A., Baeßler, C., Bonet, F.J., Carranza, F.L., Cazacu, C., Cosor, G.L., Díaz-Delgado, R., Grandin, U., Haase, P., Hämäläinen, H., Loke, R., Müller, J., Stanisci, A., Staszewski, A., Müller F. (2015). Assessment of ecosystem integrity and service gradients across Europe using the LTER Europe network, Ecological Modelling, 295, 75-87, https://doi.org/10.1016/j.ecolmodel.2014.06.019.

Petit, S., Firbank, L., Wyatt, B. ve Howard D. (2001). MIRABEL: Models for Integrated Review and Assessment of Biodiversity in European Landscapes. Ambio 30: 81-88

Sachs, J., Schmidt-Traub, G., Kroll, C., Durand-Delacre, D. ve Teksoz, K. (2017). Sustainable Development Goals Index and Dashboards Report. New York: Bertelsmann Stiftung and Sustainable Development Solutions Network (SDSN).

Singh, R.K., Murty, H.R., Gupta, S.K. \& Dikshit, A.K., (2012) An overview of sustainability assessment methodologies, In Ecological Indicators, 15 (1), 281-299.

Söderman, T., Kopperoinen L., Shemeikka P. (2012). Ecosystem Services Criteria for Sustainable Development in Urban Regions. Journal of Environmental Assessment Policy and Management. 14(2), 1-49

Sumarga, E. (2015), Spatial modelling and ecosystem accounting for land use planning Addressing deforestation and oil palm expansion in Central Kalimantan, Indonesia, Doktora Tezi, Wageningen Üniversitesi, Wageningen

Sumarga, E. ve Hein, L. (2014). Mapping ecosystem services for land use planning, the case of Central KalimantanEnvironmental Management

TEEB (2010), The Economics of Ecosystems and Biodiversity: Mainstreaming the Economics of Nature: A Synthesis of the Approach, Conclusions and Recommendations of TEEB.

Tezer, A., Çetin N.İ., Onur A.C., Menteșe E.Y., Albayrak İ., Cengiz E., (2015) Ömerli Havzası́nda Ekosistem Servislerine Dayalı Bütünleşik Havza Yönetim Planının Geliştirilmesi Projesi Sonuç Raporu, İstanbul

Tscherning, K., König, H., Schösser B., Helming K., Sieber, S., (2008) Ex Ante Impact Assessments (IA) in the European Comission - An Overview, (Ed) Helming K., Perez-Soba M., Tabbush P., Sustainability Impact Assessment of Land Use Changes, Springer, Wagenningen, Hollanda

BM-HABITAT, (2011). Cities and Climate Change: Global Report on Human Settlements

BM-HABITAT, (2002). Johannesburg Declaration on Sustainable Development BM-SDG, (2017). Sustainable Development Goals Report

BM-World Commission on Environment and Development (1992). Agenda 21: Programme of Action for Sustainable Development

UN-World Commission on Environment and Development. (1987). Brundtland Report (Our Common Future)

URL-1- (https://github.com/DotSpatial/DotSpatial https://dotspatial. codeplex.com/).

URL-2- (https://www.guru99.com/smoke-sanity-testing.html)

Vega-Azamar, R.E.; Romero-López, R.; Glaus, M.; Oropeza-García, N.A.; Hausler, R. (2015). Sustainability Assessment of the Residential Land Use in Seven Boroughs of the Island of Montreal, Canada. Sustainability, 7, 2454-2472.

Wheeler, S. M., (2013). Planning for sustainability: creating livable, equitable and ecological communities. 2nd Edition, New York, Routledge Publishing

White, R., \& Whitney, J. (1992). Cities and Environment: An Overview. R. Stren et al. (Eds.), Sustainable Cities: Urbanization and the Environment in International Perspective (s. 8-59). Boulder, Westview Press.

Wiggering, H., Mueller, K., Werner, A. and Helming, K. (2003) The Concept of Multi-Functionality in Sustainable Land Development. In: Helming, K. and Wiggering, H., Eds., Sustainable Development of Multifunctional Landscapes, Springer, Berlin, Heidelberg. http://dx.doi. org/10.1007/978-3-662-05240-2_1

van Lier, H.N. (1998), The role of land use planning in sustainable rural systems, In Landscape and Urban Planning, 41 (2), 83-91. 


\section{EK-I}

\section{Endeks Karşılaştırması}

Yöntemde esas alınan ES bileşenlerinin çevresel sürdürülebilirliğin tanımlanmasında tutarlı/uygun sonuç üretip üretmediğinin anlaşılması için çevresel sürdürülebilirliğin ölçülmesi amacıyla geliştirilmiş farklı bir endeks sonuçlarıyla karşılaştırılması yöntemin tutarlıı̆ı̆ın doğrulanması için önem taşımaktadır. Bu doğrultuda Birleşmiş Milletler tarafından 2015 yılında geliştirilmiş olan SDG'yi temel alan ve ülkelerin sürdürülebilir kalkınma performansını analiz eden "Sürdürülebilir Kalkınma Hedefleri Endeksi” (Sachs vd., 2017) uluslararası geçerliği itibariyle karşılaştırma yapılmak üzere tercih edilmiştir. SDG göstergeleri ekonomik, toplumsal ve çevresel boyutlarla ilişkili farklı bileşenleri bünyesinde barındırdığından karşılaştırma sürecinde mekânsal planlama ve çevre ilişkisine yönelik "sürdürülebilir kent ve toplumlar (SDGII)", "iklim eylemi" (SDG I 3), "su altı yaşamı (SDG I4)" ve "kara yaşamı (SDG I5)" başlıkları temel alınmıştır. Bu karşılaştırma işlemiyle; EnSAT ile yapılan hesaplama sonuçları ile SDG sonuçlarının örtüşüp örtüşmediğinin tespiti hedeflenmektedir. Daha önce de vurgulandığı üzere EnSAT yazılımının temel amacı aynı mekâna ait plan ve mevcut arazi kullanımı arasındaki farkın ortaya konması olduğu için; her iki veri (plan ve arazi) için de ÇS düzeyi hesaplanmaktadır. Ancak SDG kapsamındaki ülkelerin karşılaştırılmasındaki temel amaç EnSAT ile hesaplanan ÇS düzeyinin farklı bir endeks ile tutarlı sonuç üretip üretmediğinin belirlenmesi olduğu için, bu karşılaştırma işleminde seçilen ülkelerin yalnızca arazi örtüsü verileri EnSAT ile analiz edilmiştir. Bu da EnSAT yazılımının geliştirilme prensibinden farklı olarak; farklı mekâna ait verilerin karşılaştırılması anlamına gelmektedir. Bu nedenle söz konusu karşılaştırmanın yapılabilmesi için yakın coğrafi konumlarda; benzer ekolojik, ekonomik ve kültürel niteliklere sahip ve küresel sürdürülebilirlik performanslarıyla öne çıkan ülkeler arasında yer alan dört İskandinav ülkesi (Norveç, İsveç, Finlandiya ve Danimarka) seçilmiştir. Bununla birlikte her ne kadar bu ülkeler benzer sosyo-ekonomik niteliklere ve yakın coğrafi konumlara sahip olsalar da; ülkelerin nüfus büyüklüklerindeki ve alansal büyüklükleri arasındaki farklar EnSAT sonuçların normalize edilmesi zorunluluğunu doğurmuştur.

Bu bağlamda dört ülkenin sürdürülebilirlik performansları, toplam sürdürülebilirlik puanlarının nüfusa bölünmesiyle elde edilmiş ve sıralanmıştır. Böylelikle geliştirilen yöntem kullanılarak üretilen ülke sıralamasının Sürdürülebilir Kalkınma Hedefleri Endeksi'ndeki ülke sıralamasıyla paralel sonuçlar ortaya koyduğu görülmüştür (Tablo 7). Bu durum araştırmada geliştirilen yöntemi, yöntem içeriğindeki performans ölçüm kriterlerinin ve çıktı sonuçların uluslararası geçerlilikteki endeks bulgularıyla örtüştüğünü göstermektedir.

\section{EnSAT Yazılımının Yöntem Adımlarını Uygulama Doğruluğu}

EnSAT yazılımının araştırma kapsamında geliştirilen yöntem adımlarını doğru bir şekilde uygulayıp uygulamadığının test

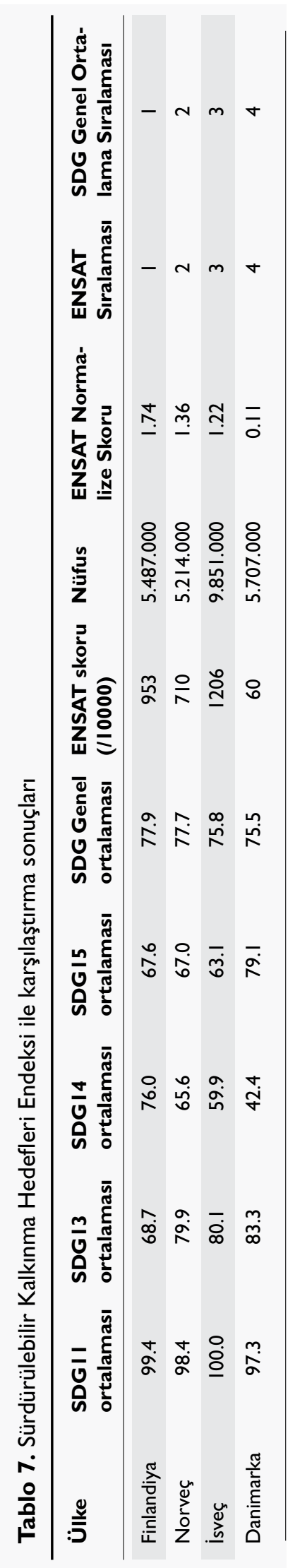


edilmesi için İstanbul'da seçilen bir bölgede örnek uygulama gerçekleştirilmiştir. Bu uygulama Şekil 3'de seçilen bölge için gerçekleştirilmiştir. Bu testin sağlanabilmesi için EnSAT ile gerçekleştirilen bir analizin, farklı bir yazılım vasıtasıyla gerçekleştirilmesi durumunda da aynı sonucu vermesi beklenmektedir. Bu doğrultuda örnek alana ait Corine Arazi Örtüsü ve ÇDP verileri Microsoft Excel programına uyumlu hale getirilerek tüm hesaplamalar mekânsal gösterimden bağımsız olarak Microsoft Excel ortamında yürütülmüştür. Sayısal olarak yapılan bu analizler sonucunda EnSAT sonuçları (Şekil 4) ve Excel sonuçlarının (Tablo 8 ve Tablo 9) birebir aynı olduğu görülmüştür.

\section{Makullük Testi}

Makullük testi (sanity test) yazılım algoritmalarının temelinde kullanılan yöntem veya modellerin herkes tarafından kabul görmüş gerçeklerle uyumlu sonuçlar üretip üretmediğinin sorgulanmasında kullanılan geçerlilik testlerinden biridir (https:// www.guru99.com/smoke-sanity-testing.html). Bu bağlamda EnSAT yazılımı için makullük testi İstanbul'da ekolojik yapıları belirgin farklılıklar gösteren Şile ve Zeytinburnu ilçeleri örneklemleri temel alınarak gerçekleştirilmiştir.

Şekil 7 ve Şekil 8'da arazi kullanım dağılımı sunulan ilçeler incelendiğinde, Şile'nin yaklaşık 60.000 hektarlık orman varlığı, buna bağlı ekosistem zenginliği ve sınırlı kentleşmiş dokusu göze çarpmakta; Zeytinburnu'nun ise doğal çevreden yoksun, yoğun yapılaşmış bir niteliğe sahip olduğu görülmektedir. İlçeler arası arazi kullanımındaki bu ciddi farklıklara bağı olarak Şile ilçesinin Zeytinburnu ilçesinden daha yüksek ÇS düzeyinde olması beklenmektedir.

Bu beklenti temelinde makullük testi kapsamında Şile ve Zeytinburnu ilçelerinin 2006 tarihli Corine Arazi Örtüsü verisi kullanılarak EnSAT yazılımında ÇS performansları hesaplanmıştır. EnSAT sonuçlarına göre Zeytinburnu ilçesinin mekânsal kullanım sürdürülebilirliği - 19 puan alırken, Şile ilçesinin puanı 232 olarak hesaplanmıştır (Şekil 9). Bu duruma göre EnSAT yazılımı ve araştırma kapsamında geliştirilen yöntem makullük testini geçmektedir.

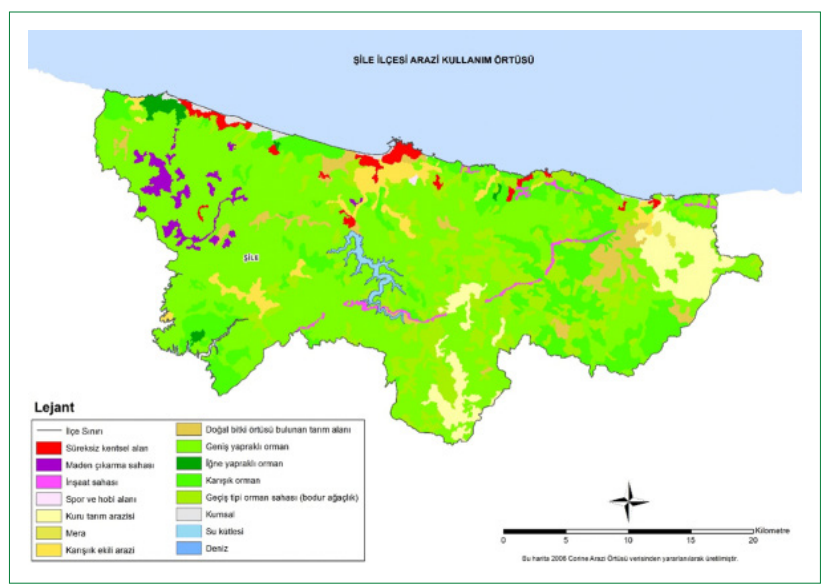

Şekil 7. Corine Arazi Örtüsü (2006) verisinden üretilmiş Şile ilçesi arazi örtüsü
Tüm bu testler sonucunda EnSAT yazılımına altlık olarak kullanılan ES türlerinin mekânsal kullanımın ÇS düzeyini belirlemede kullanılabilecek tutarlılıkta olduğu; yazılımın yöntem adımlarını doğru bir şekilde uyguladığı ve EnSAT'in en temel yazılım testi olan makullük testinden de geçtiği tespit edilmiştir.

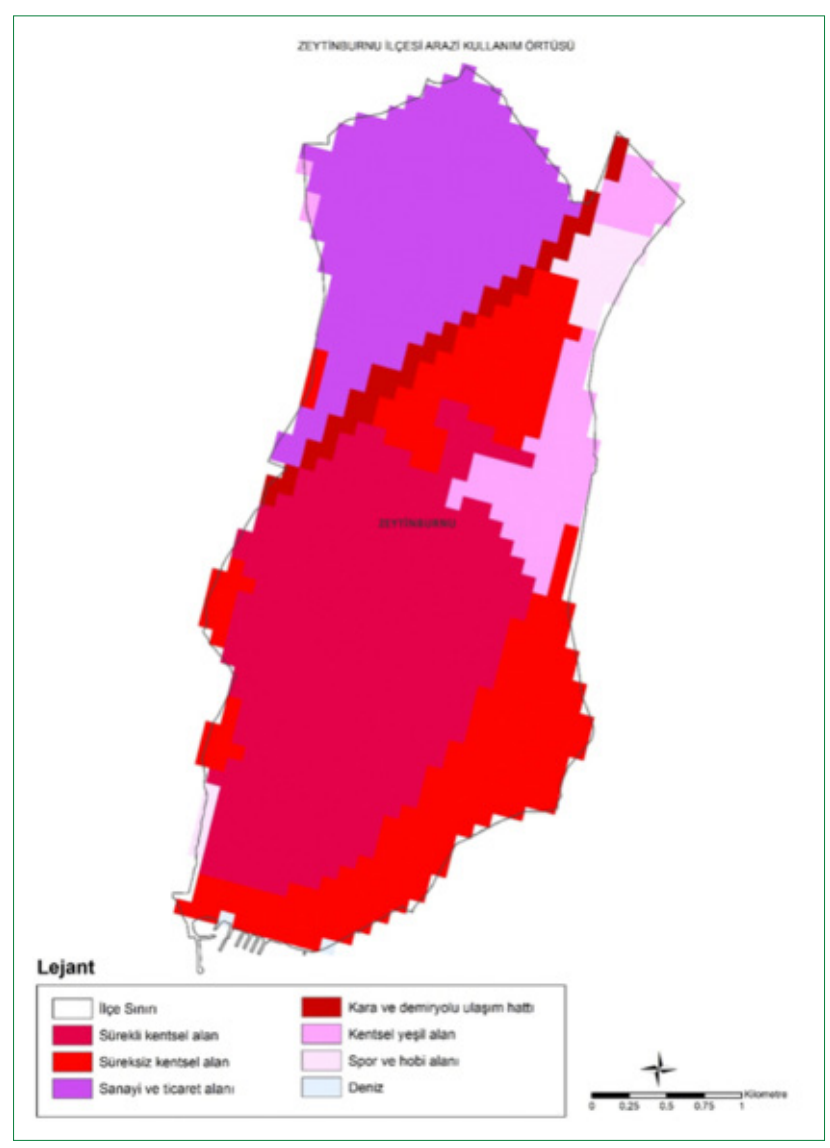

Şekil 8. Corine Arazi Örtüsü (2006) verisinden üretilmiş Zeytinburnu ilçesi arazi örtüsü

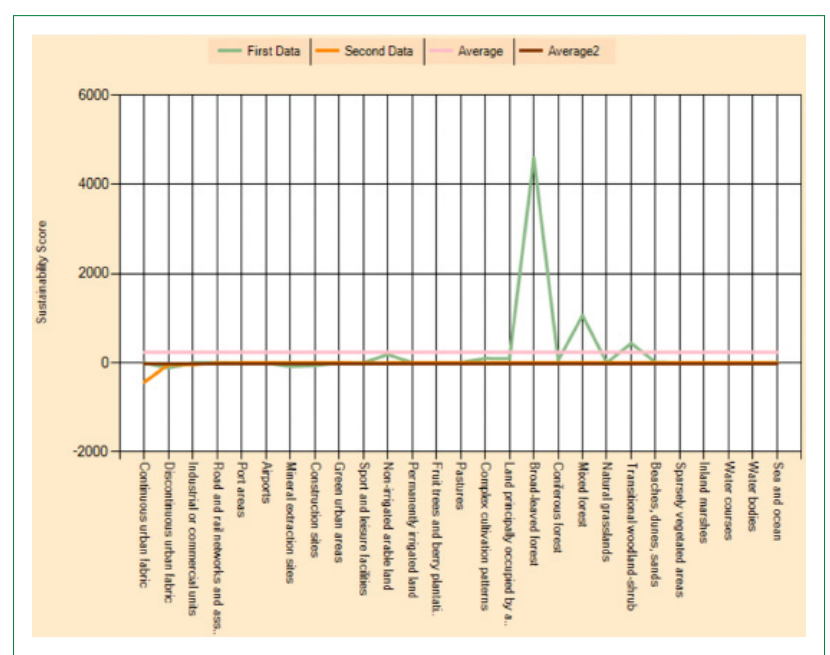

Şekil 9. Zeytinburnu ve Şile ilçelerinin çevresel sürdürülebilirlik karşılaştırma ekranı 

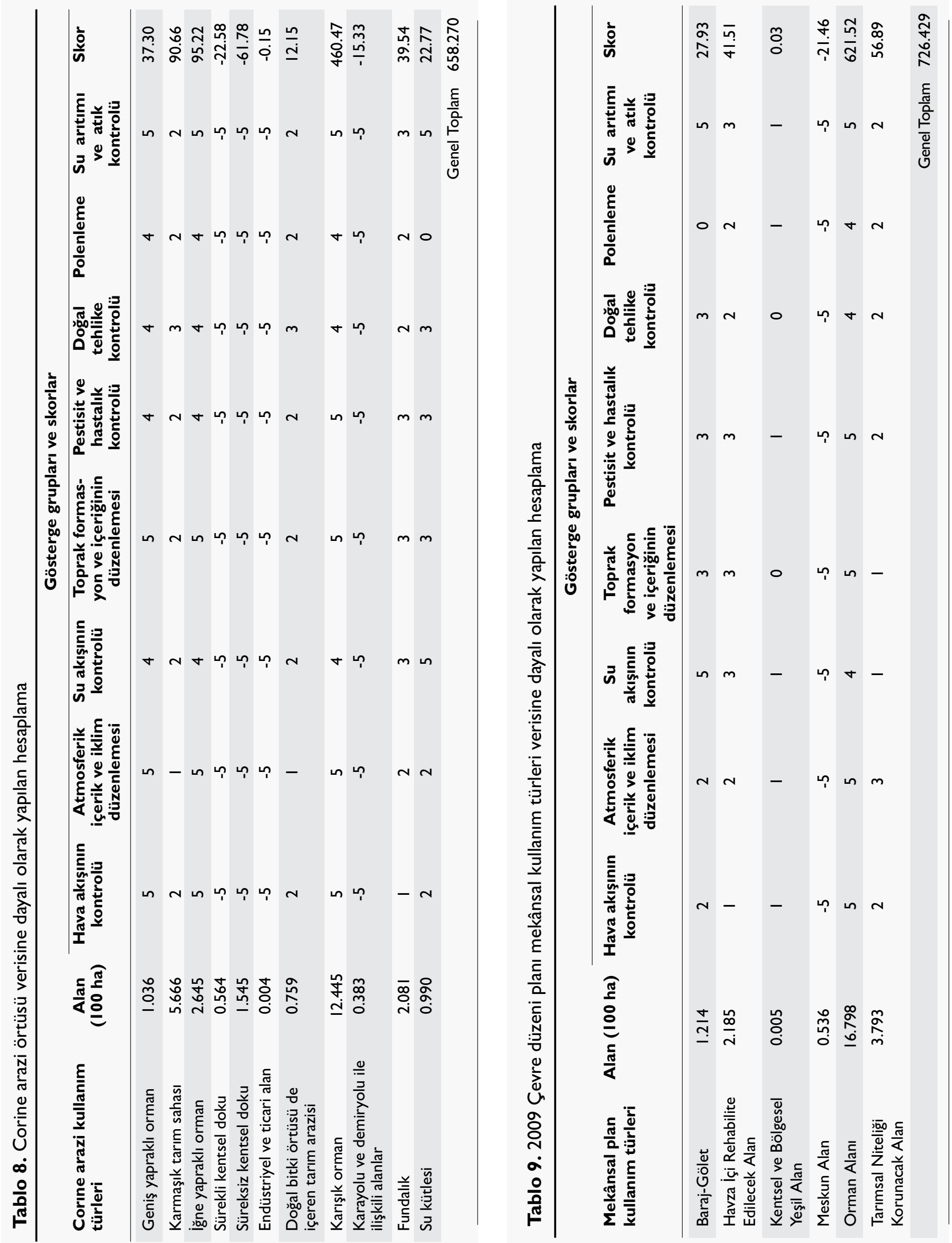